\title{
Ocular manifestations of emerging viral diseases
}

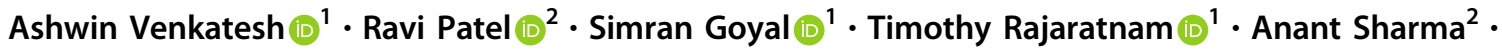 \\ Parwez Hossain ${ }^{3,4}$
}

Received: 28 June 2020 / Revised: 2 December 2020 / Accepted: 14 December 2020 / Published online: 29 January 2021

(c) The Author(s) 2021. This article is published with open access

\begin{abstract}
Emerging infectious diseases (EIDs) are an increasing threat to public health on a global scale. In recent times, the most prominent outbreaks have constituted RNA viruses, spreading via droplets (COVID-19 and Influenza A H1N1), directly between humans (Ebola and Marburg), via arthropod vectors (Dengue, Zika, West Nile, Chikungunya, Crimean Congo) and zoonotically (Lassa fever, Nipah, Rift Valley fever, Hantaviruses). However, specific approved antiviral therapies and vaccine availability are scarce, and public health measures remain critical. Patients can present with a spectrum of ocular manifestations. Emerging infectious diseases should therefore be considered in the differential diagnosis of ocular inflammatory conditions in patients inhabiting or returning from endemic territories, and more general vigilance is advisable in the context of a global pandemic. Eye specialists are in a position to facilitate swift diagnosis, improve clinical outcomes, and contribute to wider public health efforts during outbreaks. This article reviews those emerging viral diseases associated with reports of ocular manifestations and summarizes details pertinent to practicing eye specialists.
\end{abstract}

\section{Introduction}

Emerging infectious diseases (EIDs) pose a considerable ongoing threat to humanity. The World Health Organization (WHO) define EIDs as those that are either novel and severely affect a population for the first time, or those that have existed previously but have a rapidly increasing incidence or degree of spread to new geographical areas [1]. Globalisation and climate change have led to an acceleration in the emergence of EID outbreaks in recent times, with the WHO reporting 1483 epidemic events in 172 countries between 2011 and 2018 [2]. Since infectious diseases are

These authors contributed equally: Ashwin Venkatesh, Ravi Patel

Parwez Hossain

P.N.Hossain@soton.ac.uk

1 School of Clinical Medicine, University of Cambridge, Cambridge, UK

2 Moorfields Eye Hospital, London, UK

3 Eye Unit, University Hospitals Southampton NHS Foundation Trust, Southampton, UK

4 Clinical Experimental Sciences, Faculty of Medicine, Univeristy of Southampton, Southampton, UK increasingly extending beyond endemic territories, the clinician should be armed with a global perspective.

Recent outbreaks combined with the development of diagnostic techniques have increasingly allowed characterisation of the ocular manifestations of EIDs [3]. The most prominent outbreaks in recent times have constituted viruses such as the 2014-2016 Ebola outbreak in West Africa, 2015-2016 Zika outbreak in the Americas, a series of increasingly frequent Dengue outbreaks and the current severe acute respiratory syndrome coronavirus 2 (SARSCoV-2) pandemic [4-7]. With the necessary precautions, eye specialists are therefore in a position to facilitate swift diagnosis, improve clinical outcomes and contribute to wider public health efforts during outbreaks. To this end, we provide a timely review of emerging viral diseases for the ophthalmologist (Table 1).

\section{Methodology}

Emerging viral diseases were identified for inclusion using the WHO list of designated 'priority' pathogens as well as an initial scoping literature search for emerging viral diseases with ocular manifestations [8]. For each virus identified for inclusion, an in-depth literature search was performed using MEDLINE's database, with variations on virus name, emerging disease, and ocular manifestations, as key search terms. 
Table 1 Summary table of emerging viral diseases with ocular manifestations, detailing their epidemiology and presentation, and grouped according to primary mode of transmission. Emerging viral diseases with ocular manifestations.

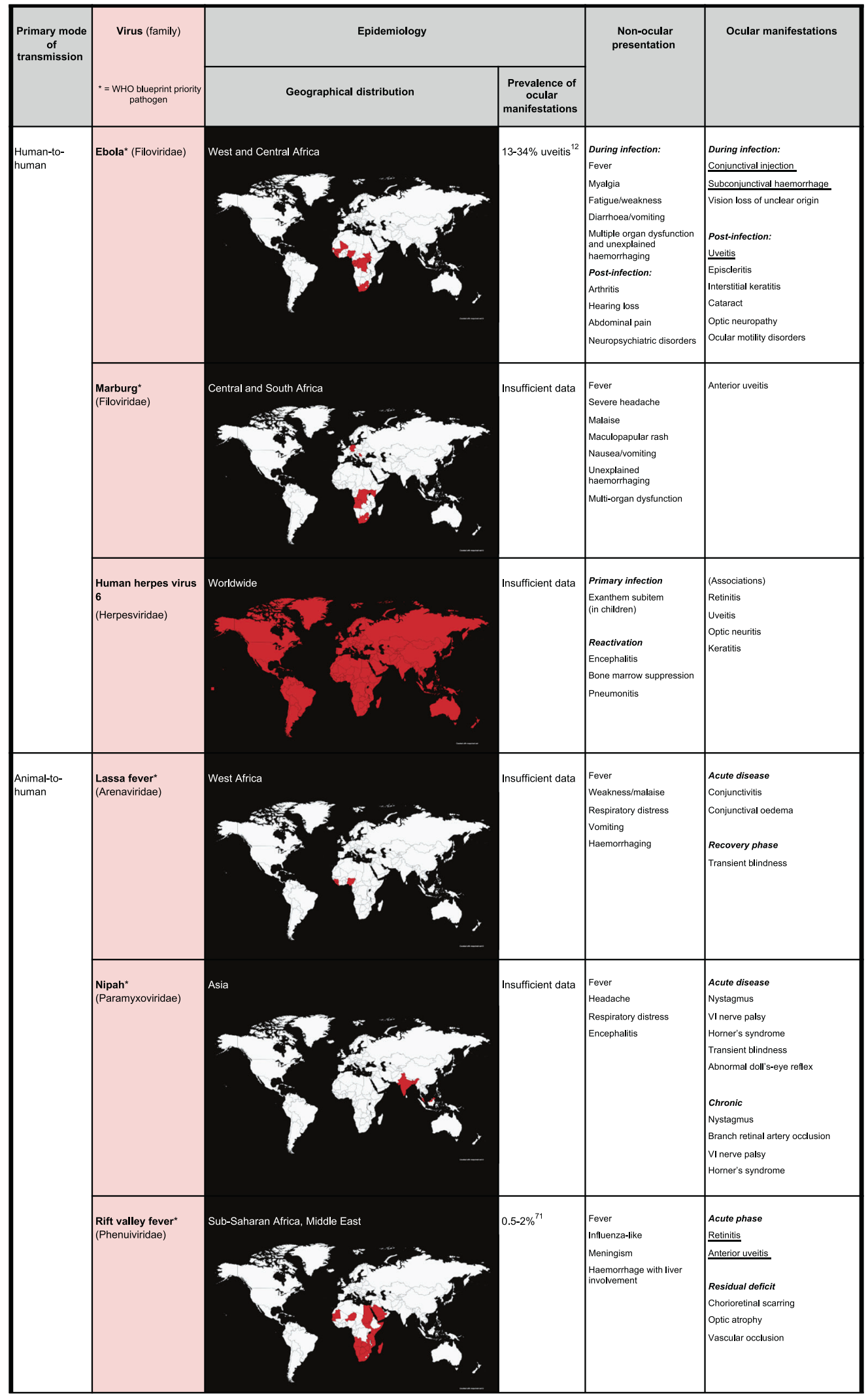


Table 1 (continued)

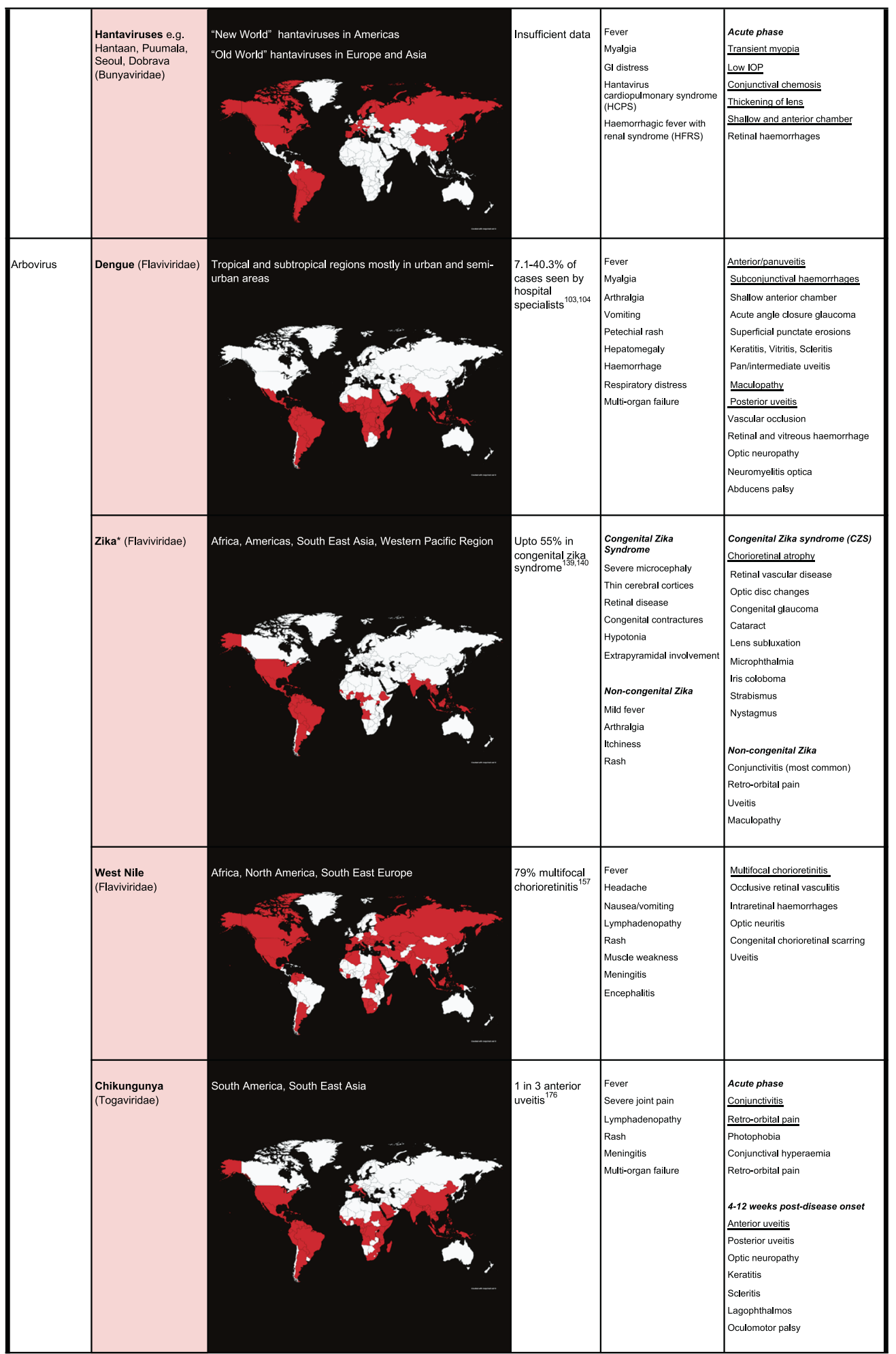


Table 1 (continued)

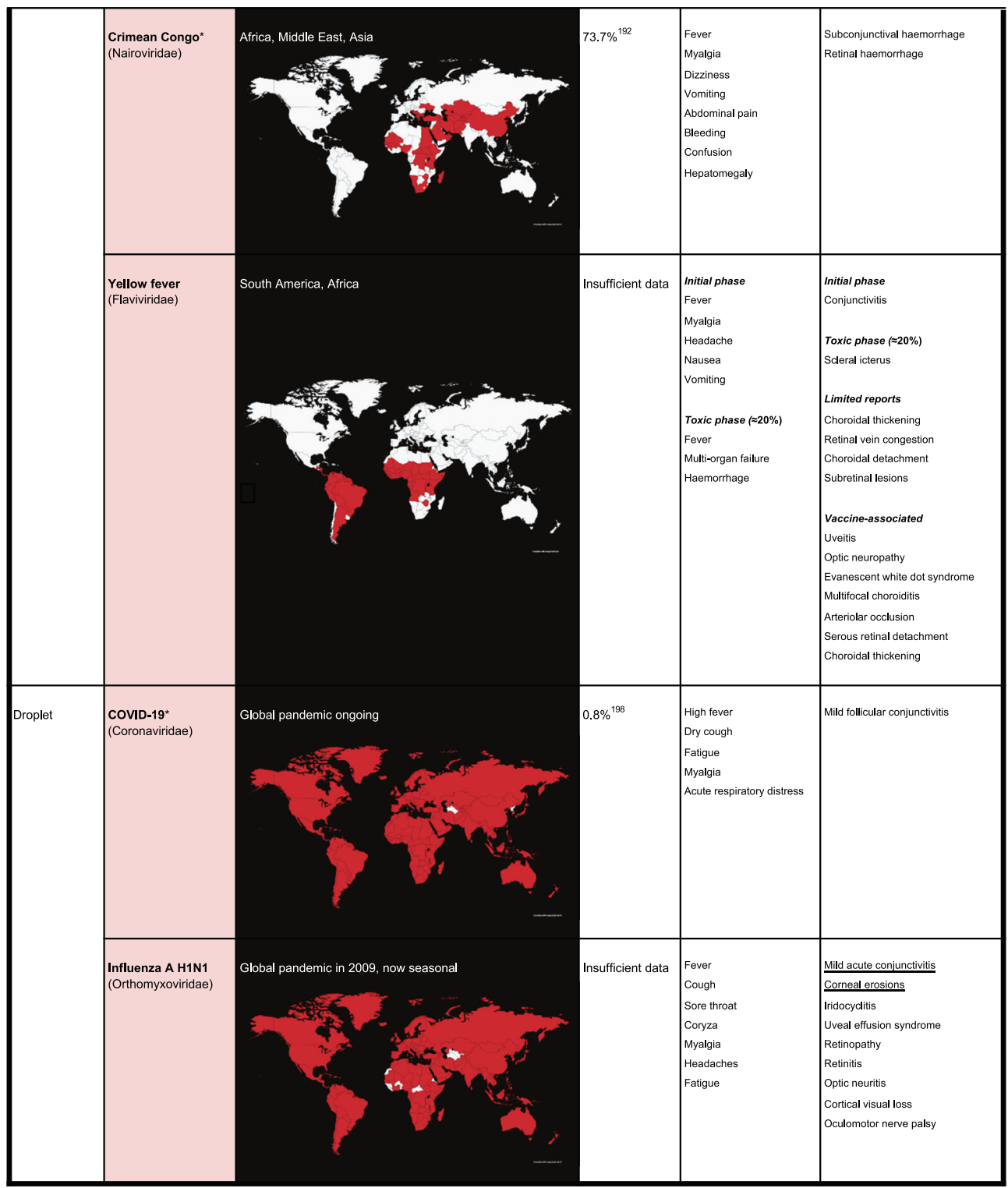

Emerging viral diseases with ocular manifestations.

Studies selected were in English and pertaining to humans. Searches were supplemented by reviewing reference lists of relevant papers. The viruses discussed will be grouped according to the mechanism of transmission and family.

\section{Human-to-human}

\section{Ebola* (Filoviridae)}

Ebola virus (EBOV) is an enveloped, filamentous, negativesense, single-stranded RNA virus of the Filoviridae family.
EBOV is the cause of the frequently lethal Ebola virus disease (EVD), which has a documented case fatality rate of around $50 \%$ [9]. EVD outbreaks typically start from a single case of probable zoonotic transmission, and fruit bats, likely of the Pteropodidae family, are believed to be the natural reservoir for the virus. Human-to-human transmission then occurs via direct contact, or contact with infected bodily fluids or contaminated fomites. The unprecedented 2013-2016 Western African EVD outbreak (the largest in history: 28,600 cases and 11,300 deaths) and the ongoing EVD outbreak in the Democratic Republic of the Congo have shed light on the spectrum of manifestations of EVD [10]. 
After contact with the virus, the asymptomatic incubation period ranges from 2 to 21 days with an average of 8 to 10 days. EVD is typically characterized by an initial fever, myalgias and fatigue, progressing to gastro-intestinal symptoms (diarrhoea and vomiting) and eventually a fatal multiple organ dysfunction syndrome. During acute infection, ocular manifestations include conjunctival injection (48-58\%; often bilateral), subconjunctival haemorrhages and vision loss of unclear origin [4].

An important clinical sequel has surfaced in survivors, termed the 'post-Ebola virus disease syndrome'. This commonly manifests with ocular disease $(60 \%)$, and may be accompanied by arthritis, hearing loss, abdominal pain and neuropsychiatric disorders as well as viral persistence in immune-privileged organs [11]. Uveitis is the most common ocular complication, occurring in $~ 13-34 \%$ of EVD survivors in West Africa within the first 12 weeks (but sometimes even after a year) following convalescence [12]. This commonly presents with eye pain, redness and photophobia and may lead to acute or chronic vision loss, with a unilateral predominance [13]. Within uveitis, case series quote variable prevalence statistics, overall indicating anterior uveitis as most frequent, followed by posterior uveitis, and rarely panuveitis [14-16]. Slit lamp examination often shows non-specific signs of active or past ocular inflammation e.g. posterior synechiae, keratic precipitates, anterior chamber cell and flare and conjunctival injection [17]. Multimodal imaging including fundus photography and optical coherence tomography (OCT) can be used to evaluate retinal lesions in posterior or panuveitis. A case series evaluating 14 EVD survivors noted retinal lesions that were predominantly non-pigmented with perilesional areas of dark without pressure, and peripapillary lesions that exhibited variable curvatures respecting the horizontal raphe and sparing the fovea [18]. OCT showed abnormalities of the outer retinal layers (Fig. 1). In these uncontrolled cohorts, risk factors predicting uveitis include conjunctival injection, and a high viral load (corresponding to a low cycling threshold on reverse transcription PCR (RT-PCR) analysis) during acute EVD, and advanced age $[11,14]$. The PREVAIL III prospective cohort study in Liberia found that survivors exhibited more frequent uveitis than controls, and the prevalence increased during follow-up (at enrolment, $26.4 \%$ vs. $12.1 \%$; at year $1,33.3 \%$ vs. $15.4 \%$ ) [19]. Neuroophthalmic complications are also possible, including optic neuropathy and ocular motility disorders [16]. Other

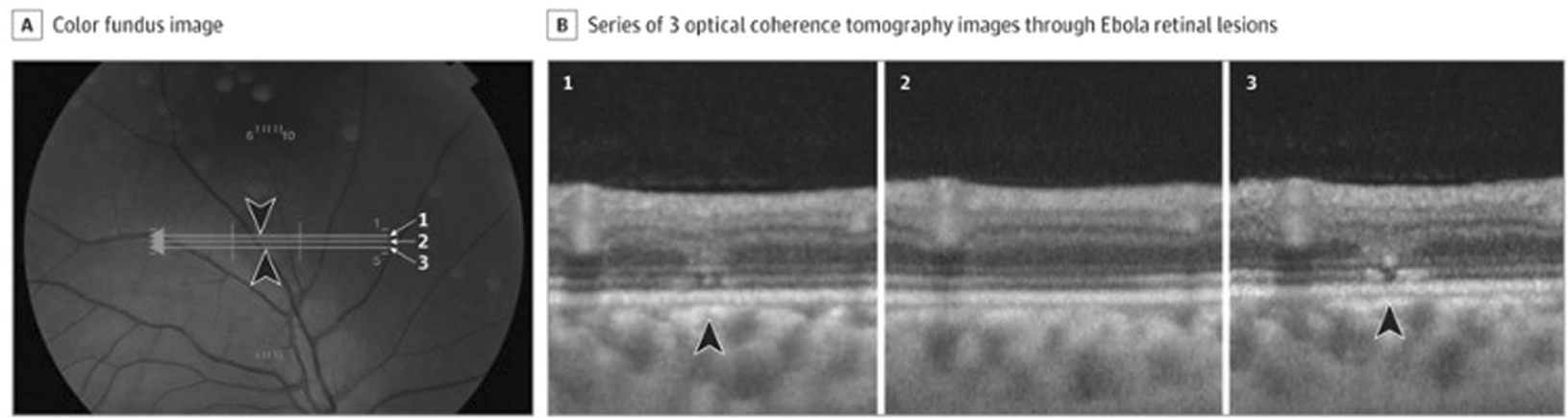

C Right eye ultra-widefield retinal image

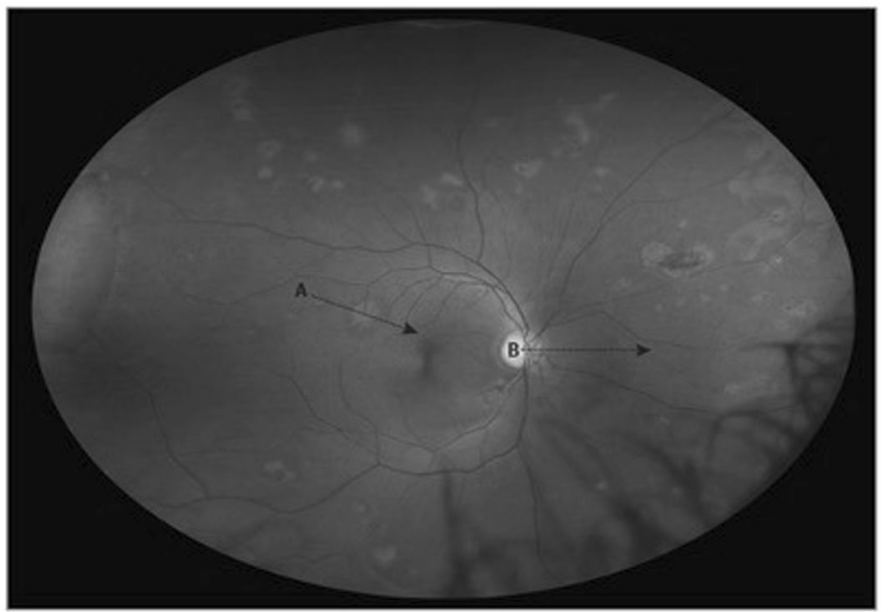

Fig. 1 Ebola retinal lesions. A Colour fundus image, $\mathbf{B}$ corresponding OCT images showing discontinuities in the outer retinal layers, $\mathbf{C}$ multiple non-pigmented lesions and associated perilesional areas of dark without pressure. Source: Steptoe et al. [18] (CC-BY License). 
ophthalmic sequelae include episcleritis, interstitial keratitis and cataract [4, 14, 15].

Diagnosis requires a combination of case definition and laboratory tests, typically real-time RT-PCR or enzymelinked immunosorbent assay (ELISA). This permits the swift initiation of appropriate cycloplegic and antiinflammatory treatment (topical or systemic steroids depending on severity) for uveitis and recognition and management of complications. Notably, the finding of replicating EBOV in the aqueous humour following recovery from EVD (and for at least 100 days post acute EVD diagnosis) highlights possible infectivity of ocular fluid posing risk to ophthalmologists performing invasive procedures on EVD survivors [20, 21].

Timely diagnosis can help avoid long-term visual disability. Specifically, whilst USA healthcare workers swiftly treated recovered vision following therapy, nearly $40 \%$ of eyes in a Liberian cohort in whom treatment was comparatively delayed had vision worse than 20/400 than their initial presentation, sometimes because of structural complications including cataract and dense vitreous opacity [4]. In one study of 57 patients with uveitis after EVD, 7 (12\%) were also diagnosed with cataracts concurrently with uveitis, and at least 3 others developed cataract(s) following the onset of uveitis [11]. This illustrates that interventions to counteract the resource-limited delays in uveitis diagnosis and treatment focussed in areas atrisk for EVD might help to reduce the risk of vision-related morbidity in future outbreaks. Recent evidence highlights the feasibility of establishing screening eye clinics for EVD survivors to facilitate this objective [22].

The mainstay of treatment for the underlying EBOV infection is currently supportive and symptomatic; however, antiviral drugs are emerging [23]. An experimental Ebola vaccine is now FDA-approved for the prevention of EVD in individuals aged 18 years and older [24]. It is being used in a ring vaccination protocol to control current outbreak in the Democratic Republic of the Congo [9].

\section{Marburg* (Filoviridae)}

Marburg virus (MARV) is a negative-sense RNA virus of the Filoviridae family. Zoonotic infection occurs following prolonged exposure to Rousettus aegyptiacus bats, the natural reservoir of MARV, with outbreaks mostly endemic to East and Central Africa [25]. Secondary human-tohuman transmission occurs primarily via direct contact with a symptomatic individual or their infected bodily fluids and MARV is known to persist in immune-privileged sites following recovery [26, 27]. After an incubation period of 2-21 days, Marburg virus disease (MVD) typically presents abruptly with high fever, severe headache and malaise, often with gastro-intestinal disturbance and a maculopapular non-pruritic rash. The development of haemorrhagic manifestations between 5 and 7 days signals late stage disease and case fatality rates between 23 and $90 \%$ have been recorded [28]. Ocular involvement is limited to a single case report of acute anterior uveitis developing during convalescence (3 months following acute MVD onset), which was successfully treated with topical steroids, atropine and acetazolamide [29, 30]. MARV can persist after resolution of symptoms or death in various human tissues, secretions and even immune-privileged sites. This is a finding supported more recently by primate studies highlighting viral persistence in the eye [27, 31]. Diagnosis is made by RT-PCR from blood or buccal swab, and a negative test does not rule out infection until symptoms have been present for at least $72 \mathrm{~h}$ [32]. There is no specific antiviral treatment or vaccine at present; aggressive supportive care and fluid resuscitation complemented by public health measures form the mainstay of management [27, 33].

\section{Human herpes virus-6 (HHV-6)}

HHV-6 is a double-stranded DNA virus of the $\beta$-herpes virus subfamily found worldwide, with two variant species HHV$6 \mathrm{~A}$ and HHV-6B. Little is known about the acquisition or prevalence of HHV-6A and it is less associated with disease [34]. In contrast, HHV-6B, which has a seroprevalence approaching $100 \%$, with infection typically occurring in childhood [35]. The virus replicates in the salivary glands and is transmitted through the saliva. HHV-6 mRNA has been detected in the ocular fluid sample of a patient with uveitis suggesting that viral replication may occur in the eye [36]. Additional tests for HHV-6 RNA or protein in ocular tissues would provide more definitive evidence of this.

There are typically three stages in the natural history of HHV-6 infection [35]. Acute primary infection in childhood causes exanthem subitum [37], also called roseola infantum. This is characterised by a high fever followed by a rash that spontaneously resolves. Complications include CNS invasion, hepatitis and pneumonitis, in both immunocompetent and immunosuppressed patients. The second stage occurs in healthy adults and children where the virus remains latent in lymphocytes and monocytes and stays at a low level in tissues. The third stage is due to reactivation from latency or reinfection in immunosuppressed patients.

Ocular conditions of the posterior segment are more commonly associated with HHV-6, though the exact role of HHV-6 in these conditions remains unclear. Posterior segment inflammation associated with HHV-6 includes AIDSassociated retinitis [38-41], uveitis [36, 42-46] and optic neuritis [46-49]. The prevalence of HHV-6 in ocular fluid samples of patients with ocular inflammation has been found to be $2 \%$ or less $[36,42,43]$. The largest study to date found 7/350 patients with uveitis or endophthalmitis tested positive for HHV-6 DNA in ocular fluid samples [36]. The 
detection of HHV-6 DNA in the eye may not be clinically relevant as all seven patients were found to have other infectious agents in ocular fluid samples. Therefore, it is assumed that HHV-6 infections play a secondary role in the pathogenesis of ocular inflammation [36]. Presence of HHV-6 DNA can be accounted for as it latently resides in immune cells [35], which may enter the eye during inflammation due to destruction of the blood-retinal barrier [36]. Alternatively, HHV-6 DNA detected in intraocular fluids may be due to release of HHV-6 DNA from resident ocular cells caused by intraocular inflammation and this is supported by findings that HHV-6 can infect human retinal pigment epithelial cells [50].

In addition, reactivation of HHV-6 frequently accompanies CMV reactivation [51]. In nine patients with AIDSassociated retinitis, three were positive for HHV-6 and all three had simultaneous CMV coinfection [41]. This suggests that presence of HHV-6 may simply reflect the immunocompromised state of the patient.

Anterior segment disease associated with HHV-6 includes corneal inflammation [36, 52, 53]. HHV-6 was detected in 14/ 22 patients with corneal inflammation, specifically, dendritic keratitis, corneal ulcer or keratouveitis. This study showed the association of HHV-6 with disease is more frequent than other herpesviruses suggesting that HHV-6 may be another sole causative agent for corneal inflammation [52].

Diagnosis of clinically relevant HHV-6 is challenging due to the high prevalence of infection and need to distinguish between active and latent infections [36]. Detection of HHV-6 DNA in the plasma or serum indicates active infection [54]. Quantitative PCR can distinguish between active and latent infections of clinical samples tested, such as aqueous humour, vitreous or corneal samples. Multiplex PCR of the aqueous humour should be performed in suspected cases for early diagnosis of HHV-6 and specific antiviral therapy initiation [45, 46]. Foscarnet, ganciclovir, either alone or in combination and cidofovir should be used for management of HHV-6-related neurological disease and seems to be more efficient than acyclovir $[45,55,56]$.

\section{Animal-to-human}

\section{Lassa fever (LF)* (Arenaviridae)}

Lassa virus (LASV) is an enveloped, negative-sense, singlestranded, bi-segmented RNA virus of the Arenaviridae family and is endemic to West Africa. Infection often occurs through exposure to food or household items contaminated with urine or faeces of infected Mastomys rats. Person-to-person transmission may occur after exposure to virus in bodily fluids, particularly in healthcare settings in the absence of control measures. Following a 7-21-day incubation period, LASV can cause Lassa fever (LF), an acute viral haemorrhagic illness with an overall case fatality rate of $1 \%$, though most-affected individuals harbour the infection asymptomatically (80\%) [57]. Ocular involvement is not extensively reported for LF, with a single case series noting conjunctivitis and conjunctival oedema in acute LF, whilst transient blindness has been documented during convalescence [58-60]. Animal studies highlight high viral loads present in the aqueous humour in rhesus macaques that died of experimental LASV infection [30]. LF is most often diagnosed by ELISA to detect $\operatorname{IgM}$ and $\mathrm{IgG}$ antibodies as well as Lassa antigen. Ribavirin seems to be an effective antiviral therapy early in the disease course, but its use as post-exposure prophylaxis is unsupported [61, 62]. There is currently no vaccine that protects against LF. Together, these findings support minimal long-term effects on vision in LF-further longitudinal studies are necessary to clarify this association, and in the meanwhile careful ophthalmic observation of LF survivors is recommended.

\section{Nipah* (Paramyxoviridae)}

Nipah virus is an enveloped, negative-sense, single-stranded RNA virus in the family Paramyxoviridae of the genus Henipavirus. It was first isolated during the 1999 outbreak in Malaysia and Singapore. Repeated outbreaks have since occurred in India and Bangladesh. Transmission is primarily zoonotic from contact with infected pigs or bats, though person-to-person transmission has also been reported in Bangladesh and India, highlighting its pandemic potential [63]. There are currently no studies on viral persistence in bodily fluids.

The disease has a high mortality rate of $40 \%$ (Malaysia) to over $70 \%$ (India) [63]. Variation in mortality rates and clinical features in the two regions are likely due to different strains, which have separately co-evolved. The incubation period is from 4 to 21 days, followed by up to 2 weeks of fever and headache. Fatal encephalitis is the main complication of the disease and acute respiratory disease occurs to varying degrees.

Regarding ocular manifestations, one small study from Singapore of 13 patients reported nystagmus, VI nerve palsy and transient blindness during the acute phase of the illness [64]. Residual clinical signs at an 18-month followup included nystagmus, branch retinal artery occlusion, VI nerve palsy and Horner's syndrome [64]. Retinal artery involvement is consistent with the hypothesis of vasculitic small-vessel infarction. Another study found that abnormal doll's-eye reflex and pin-point pupils with variable reactivity were associated with a higher mortality suggesting greater brain stem involvement [65]. These two studies examined symptoms in pig farmers in Singapore or Malaysia. Therefore, further characterisation of ocular 
manifestations of the more pathogenic viral strains in Bangladesh and India is needed [66].

Diagnosis focuses on RT-PCR of throat swabs, blood, urine and CSF [67]. There is no approved vaccine and treatment is largely supportive with evidence for ribavirin treatment being equivocal $[65,68]$.

\section{Rift valley fever (RVF)* (Phenuiviridae)}

RVF virus is an enveloped, negative-sense, single-stranded RNA virus, of the family Phenuviridae [69]. It is the cause of RVF, a zoonotic arthropod-borne disease, mainly affecting cattle. With an incubation period of 2-6 days, most human infections follow contact with the blood or organs of infected animals, typically occupationally. A smaller number occurs via mosquito bite (Aedes or Eretmapodites genus), and there are no documented cases of human-to-human transmission [70, 71]. Outbreaks, closely related to high-rainfall conditions, have mainly occurred in sub-Saharan Africa and North Africa, though more recently cases were reported in the Arabian Peninsula. In the five most recent outbreaks for which relevant data were recorded, an estimated total of 339,000 infections are believed to have occurred [72]. Documented case fatality rates are highly variable, though it is thought to be $<1 \%$ [71].

In its most common mild form, RVF is characterised by fever and non-specific flu-like symptoms. In a small percentage of cases, a severe form develops, categorised into three syndromic presentations: ocular disease with risk of permanent loss of vision; meningoencephalitis with confusion and potentially coma; and haemorrhagic fever with liver involvement and jaundice, this being the most fatal form [73].

Ocular manifestations are well-documented, and present symptomatically with blurred vision, decreased vision, floaters, scotomatous areas or periocular pain [74-82]. The classical manifestation is of macular or paramacular retinitis (Fig. 2). It is difficult to estimate the true incidence of ocular complications in RVF, as total case numbers in outbreaks are not known and incidences in case series from different outbreaks vary significantly. However, the WHO estimates an incidence of $0.5-2 \%$ patients [71]. The largest series to date looked at 143 patients (212 eyes) all with macular or paramacular retinitis and serologically proved RVF in the 2000 Saudi Arabian outbreak [75]. Onset of visual symptoms ranged from 4 to 15 days. Associated lesions included retinal haemorrhages (40\% of eyes), vitreous retractions (26\%), optic disc oedema (15\%) and retinal vasculitis $(7 \%$, mostly phlebitis, occasionally arteritis). A single creamywhite area of retinal necrosis was typically seen on fundoscopy reflecting retinitis, alongside the other described associated lesions. Fluorescence angiography demonstrated an early hypofluorescence of the area of retinitis and delayed filling of arterioles and venules, with late

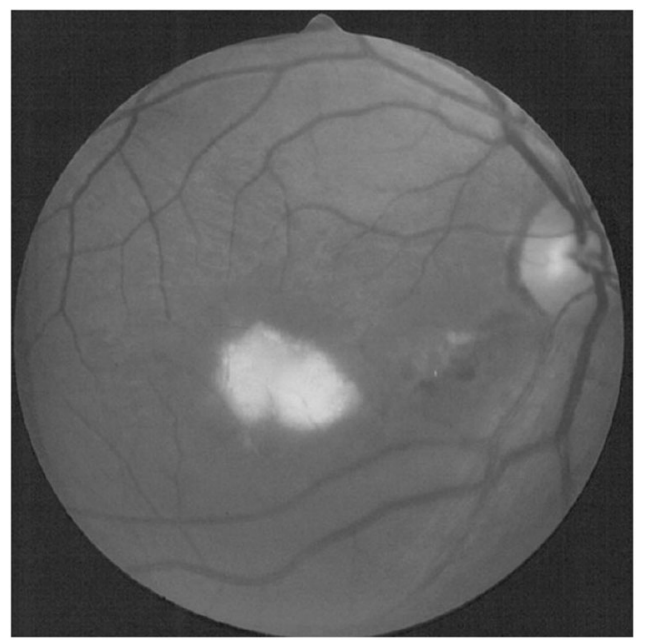

Fig. 2 Rift Valley fever virus, fundus photograph, demonstrating active retinitis in the macular region and retinal haemorrhages. Source: Khairallah [231] (CC-BY licence), original publication AlHazmi 2005.

staining of the retinal lesion and blood vessels. Active lesions largely resolved over a 9-month follow-up, leaving behind chorioretinal scarring, and in some cases vascular occlusion and optic atrophy. Seventy-one percent of eyes remained legally blind at the end of follow-up, compared to 40-50\% permanent visual loss reported in previous studies. Fifty-one eyes also developed a transient mild-to-moderate anterior uveitis, which appeared non-granulomatous.

$\mathrm{RVF}$ and its ocular manifestations may mimic other viral diseases, and so diagnosis relies on laboratory testing with either RT-PCR or serology [73]. No positive RVF viral cultures or RT-PCR have been reported as yet in CSF, or on aqueous or vitreous samples [83]. No disease-specific treatments are available, and no vaccines are licenced or commercially available for human use at present [71]. Severe cases are managed supportively.

\section{Hantaviruses e.g. Hantaan, Puumala, Seoul, Dobrava (Bunyaviridae)}

Hantaviruses are enveloped, single-stranded, negative-sense RNA viruses of the Bunyaviridae family. The viruses are rodent-borne and transmission is via aerosols of excreta, saliva and urine, leading to an initially non-specific viral presentation of pyrexia, chills and myalgias following an incubation period (10-25 days). Person-to-person transmission is generally rare for hantaviruses, with the notable exception of Andes virus (ANDV) following reports of transmission of ANDV in the hantavirus cardiopulmonary syndrome (HCPS) outbreak in Argentina in 1996 [84, 85]. Nowadays, hantavirus infections are subdivided into two groups representing the two most common clinical patterns of infection [86-88]. 'New World' hantaviruses are 
principally found in the Americas, and may cause hantavirus cardiopulmonary syndrome (HCPS), characterized by interstitial pulmonary oedema leading to shock and cardiopulmonary failure. 'Old World' hantaviruses are found mostly in Europe and Asia, and may cause haemorrhagic fever with renal syndrome (HFRS), marked by sudden and extreme albuminuria due to renal medullary damage, that may lead to renal failure.

Transient ocular involvement in hantavirus infection is now increasingly recognised, and to date, has mainly been described in the context of HFRS caused by Puumala virus. An acute, transient myopia may be the first and most cardinal ocular symptom of a hantavirus infection, and its incidence has been variably reported (12-53\%) in Puumala virus infections in Europe [89-91]. The underlying mechanism is unclear, but the leading theory involves an anterior shift of the lens due to underlying inflammation of the ciliary body [91]. Anterior shift of the lens may predispose to angle closure glaucoma, reported in exceptional cases, and may be associated with ciliochoroidal effusion [89, 92]. In the largest case series (46 patients) to date reporting on ocular involvement in patients who had recovered from acute HFRS, 70\% reported ocular symptoms during the disease course, which were often bilateral [93]. During the acute phase of infection, $88 \%$ experienced decreased intraocular pressure, $87 \%$ reduced visual acuity, $87 \%$ conjunctival chemosis, $82 \%$ thickening of the lens, $78 \%$ myopic shift, $64 \%$ shallowing of the anterior chamber and $52 \%$ shallowing of vitreous length. Aside from anterior segment changes, macular features such as dot and blot intraretinal haemorrhages and streak haemorrhages of the disc have been reported on fundus imaging [94]. Recently, the first case report of presumed hantavirus necrotizing retinitis concurrent with HFRS was confirmed by fluorescein angiographic and funduscopic findings, and in this patient visual acuity losses improved months after resolution of the infection [95]. Together, these findings highlight that a diverse range of transient ocular disturbances in hantavirus infection are probable, and generally resolve with recovery from systemic infection.

At present, there are currently no approved treatments or vaccines available for hantavirus infections [96]. Supportive management in the intensive care unit is the current mainstay of treatment, with better patient outcomes associated with ICU admission earlier in the disease course (CDC).

\section{Arboviruses}

\section{Dengue (Flaviviridae)}

Dengue viruses are enveloped, positive-sense, singlestranded, RNA viruses of the Flaviviridae family. They are the cause of dengue fever. There are four viral serotypes 1-4 with no cross-immunity, and spread is via Aedes mosquito vectors [97]. Incidence has increased 30 -fold over recent decades, and there are now an estimated 96 million symptomatic infections annually, two million cases of severe dengue, and 21,000 deaths [98-101]. Occurring in endemic-epidemic cycles in crowded tropical urban areas, the largest numbers of infections are in children in Asia and young adults in the American tropics, albeit with significant extension to other continents [102].

Dengue fever occurs 3-14 days after a mosquito bite, with development of a non-specific febrile phase lasting 3-6 days [97]. Upon fever resolution, some cases progress to a critical phase of plasma leakage into abdominal and pleural cavities, also sometimes associated with impaired haemostasis. Other findings include vomiting, petechial rash, myalgia, hepatomegaly, lymphopenia and thrombocytopenia. A convalescent phase follows. Cases of severe dengue involve dengue shock syndrome and respiratory distress secondary to plasma leakage, severe bleeding and severe end organ involvement [98].

True incidence of ocular manifestations is poorly understood, with studies only including cases that reach hospital specialists. In such studies incidence has been reported between 7.1 and $40.3 \%$, a range that likely reflects differing disease severities and differing ocular workups in each study [103, 104]. Ocular manifestations occur from days to months after dengue fever onset. Reported anterior segment manifestations include, more commonly, subconjunctival haemorrhages and anterior uveitis, and more rarely, shallow anterior chambers, acute angle closure glaucoma, superficial punctate erosions, keratitis, vitritis, intermediate uveitis and scleritis [6, 104, 105]. Anterior uveitis has been reported to present with eye pain, redness, photophobia, ciliary injection, low-grade anterior chamber cells and diffuse keratic precipitates [81].

Posterior segment manifestations most commonly include maculopathy and posterior uveitis, and less commonly vascular occlusions, panuveitis and retinal and vitreous haemorrhage [6]. Maculopathy, typically asymmetric and bilateral, is reported in $10 \%$ of hospitalised patients, and is serotype-dependent [106, 107]. Onset of symptoms in maculopathy, such as decreased visual acuity and a central scotoma, occur 3-11 days after fever onset, with recovery over 2-4 weeks; though in many cases patients remain asymptomatic [108-110]. Characteristic findings on OCT allow subclassification into three groups: (1) diffuse retinal thickening, (2) cystoid macular oedema and (3) foveolitis (Fig. 3), the latter including an orange-yellow central foveal lesion and associated with the longest persistence of scotomata [108]. Other findings include retinal haemorrhages, primarily venous vasculitic changes, and yellow sub-retinal spots [6]. Cases of rare neuro-ophthalmic complications 
Fig. 3 Dengue foveolitis in left eye. A Fundus photograph showing orange-yellow central foveal lesion B OCT scan demonstrating focal thickening of the outer neurosensory retina and retinal pigment epithelium. Source: Khairallah [231] (CCBY licence), original courtesy of Soon-Phaik Chee.
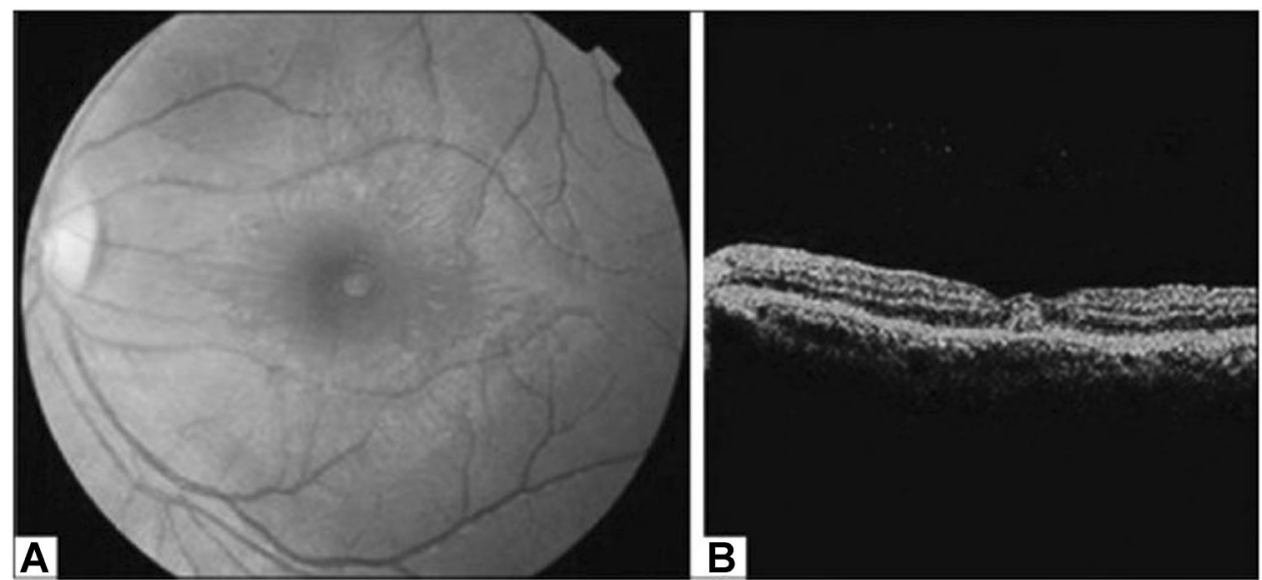

have included optic neuropathy, neuromyelitis optica and abducens palsy [6].

Diagnosis relies upon dengue symptomatology, and confirmation by laboratory testing. In the first 5 days, realtime RT-PCR or NS1 antigen detection allow confirmation. More commonly confirmation occurs after 5 days, with ELISA-based detection of anti-Dengue $\operatorname{IgM}$ or seroconversion in paired acute and convalescent serum samples [97]. Workup of posterior segment pathology to identify and grade severity of complications as well as facilitate mechanistic understanding involves visual field testing and multimodal imaging [6]. The latter includes fundoscopy, fluorescein and indocyanine green angiography, OCT for subclassification, and more recently OCT angiography [108, 111]. Ocular manifestations resolve spontaneously in the majority of cases and evidence for topical or systemic treatment with corticosteroids lacks consensus [6]. Vaccines in the latter development stages are showing some promise [112].

\section{Zika* (Flaviviridae)}

Zika virus (ZIKV) is an enveloped, positive-sense, singlestranded, RNA virus with an icosahedral capsid, and is a member of the Flaviviridae family [113, 114]. First discovered in Uganda, ZIKV has since disseminated widely throughout Africa, Asia, Pacific islands, South and Central America, causing notable outbreaks in Micronesia (2007), French Polynesia (2013) and the Americas (2015-16) [67, 109, 115].

Zika is principally transmitted via the bite of an infected Aedes mosquito (such as A. aegypti and A. albopticus), usually during daytime [116]. Human-to-human transmission can then occur via sexual contact, blood transfusions, organ donation and vertically from mother to foetus [117]. Findings of viral RNA in tears and conjunctival swabs from confirmed human cases highlight a potential ophthalmic route of transmission [118, 119].
Infected patients are typically asymptomatic, however up to $20 \%$ may develop a mild, self-limiting symptom triad of generalized maculopapular rash, arthritis or arthralgia and non-purulent conjunctivitis following a 3-14 day incubation period [117, 120, 121]. Though rare, severe neurological sequelae such as Guillain-Barré syndrome, myelitis and meningoencephalitis may develop $\sim 5$ days after acute disease onset $[122,123]$. Infection anytime during pregnancy poses up to a $10 \%$ risk of the manifestation of congenital zika syndrome (CZS) due to vertical transmission, characterised by severe microcephaly, thin cerebral cortices, retinal disease, congenital contractures and early hypertonia and extrapyramidal involvement [124-126]. The most severe CZS phenotype occurs following first trimester exposure [120, 122, 127, 128].

Ocular involvement related to Zika virus may be acquired in the acute phase or present congenitally. In the acute phase, non-purulent conjunctivitis and retro-orbital pain are the most frequent ocular signs, both reported in $40 \%$ in a Brazilian case series of 57 ZIKV positive patients [129]. Reports of uveitis are uncommon (limited to under 20 published cases) and tend to have favourable visual outcomes without recurrence [130]. Anterior uveitis may be bilateral and non-granulomatous, and is associated with high intraocular pressures, corneal oedema and minimal fine keratic precipitates, responding effectively to topical corticosteroids and anti-hypertensive drugs [131-133]. Posterior uveitis may manifest as a bilateral neuroretinitis, chorioretinitis with placoid or multifocal non-necrotizing lesions [134-136]. Reduced visual acuity can result from a unilateral acute idiopathic maculopathy occurring in the absence of uveitis, consisting of a unilateral perifoveolar greyish discoloration, and resolving within 6 weeks without treatment [137, 138].

Ocular manifestations of Zika have been described in up to $55 \%$ of infants with CZS $[139,140]$. Two characteristic manifestations include a well-circumscribed chorioretinal atrophy with a hyperpigmented border and focal pigment 
mottling at the macula, occurring in up to $70 \%$ of children with ocular findings $[116,140,141]$. This posterior eye involvement is speculated to arise from viral breakdown of the blood-retinal barrier or axonal transport along nerves [141-144]. Numerous other ocular manifestations in CZS are possible, including various optic disc changes, retinal vascular disease, congenital glaucoma and cataract, lens subluxation, microphthalmia and iris coloboma, leading to multiple deficits in visual function (e.g. contrast, visual fields, accommodation and refractive errors) [140, 141, 145]. In addition, neuro-ophthalmic manifestations such as strabismus and nystagmus have been described [141]. Risk factors predicting ocular manifestations of CZS include maternal first trimester infection and presence of microcephaly at birth.

Confirmative diagnosis of ZIKV infection requires laboratory testing of whole blood or urine, and is also possible in other bodily fluids [117]. For instance, ocular fluid testing has aided diagnosis in ZIKV anterior uveitis [131]. Testing modalities include RT-PCR, ELISA and Zika plaque reduction neutralization test (PRNT) [146]. No specific vaccines or antiviral drugs are currently available, and treatment is supportive. Regarding CZS, the French Ministry of Health and CDC recommend mandatory comprehensive ophthalmic screening in all children born to a mother infected during pregnancy, prior to 1 month of age, with a further fundus exam repeated at 1 year [147, 148]. Early detection and expedient refractive correction can lead to immediate improvements in visual function in these children [149].

\section{West Nile (Flaviviridae)}

West Nile virus (WNV) is an enveloped, positive-sense, singlestranded RNA virus of the Flaviviridae family, and a member of the Japanese encephalitis serocomplex of viruses [150]. WNV has five distinct phylogenetic lineages with only lineage one, distributed worldwide, and two, enzootic in Africa, known to cause disease in humans $[150,151]$. The natural reservoir of WNV is birds, with transmission to humans occurring via Culex mosquitoes. Bird-mosquito-human transmission leads to the vast majority of disease in humans $[150,152]$.

Of patients who contract the virus, $\sim 75 \%$ are asymptomatic, $25 \%$ develop West Nile fever (WNF) and $<1 \%$ a neuroinvasive disease fatal in $10 \%$ [150,153-155]. After an incubation period of around 2-14 days, WNF presents as a self-limiting, non-specific viral illness including fever, headache, fatigue, nausea and vomiting, lymphadenopathy and skin rash, that typically lasts less than a week [150]. Neuroinvasive disease causes meningitis, encephalitis, acute flaccid paralysis, movement disorders or other neurological manifestations $[150,156]$. Advanced age is the strongest predictor of severe neurological manifestations and fatality [150].

Multifocal chorioretinitis (Fig. 4D) is the most common ocular finding in WNV, typically bilateral, and occurring in 23 of $29(79 \%)$ consecutive patients with laboratory confirmed WNV in the largest relevant prospective study to date [157]. Patients are frequently asymptomatic, though symptoms can include floaters, reduced visual acuity, redness, ocular pain, visual field defects or diplopia $[157,158]$.
Fig. 4 West Nile virus retinopathy. A Inflammatory vascular sheathing, $\mathbf{B}$ retinal necrosis, $\mathbf{C}$ multifocal chorioretinitis, D pigmented chorioretinal scars. Source: Hasburn [232] (CC-BY licence).

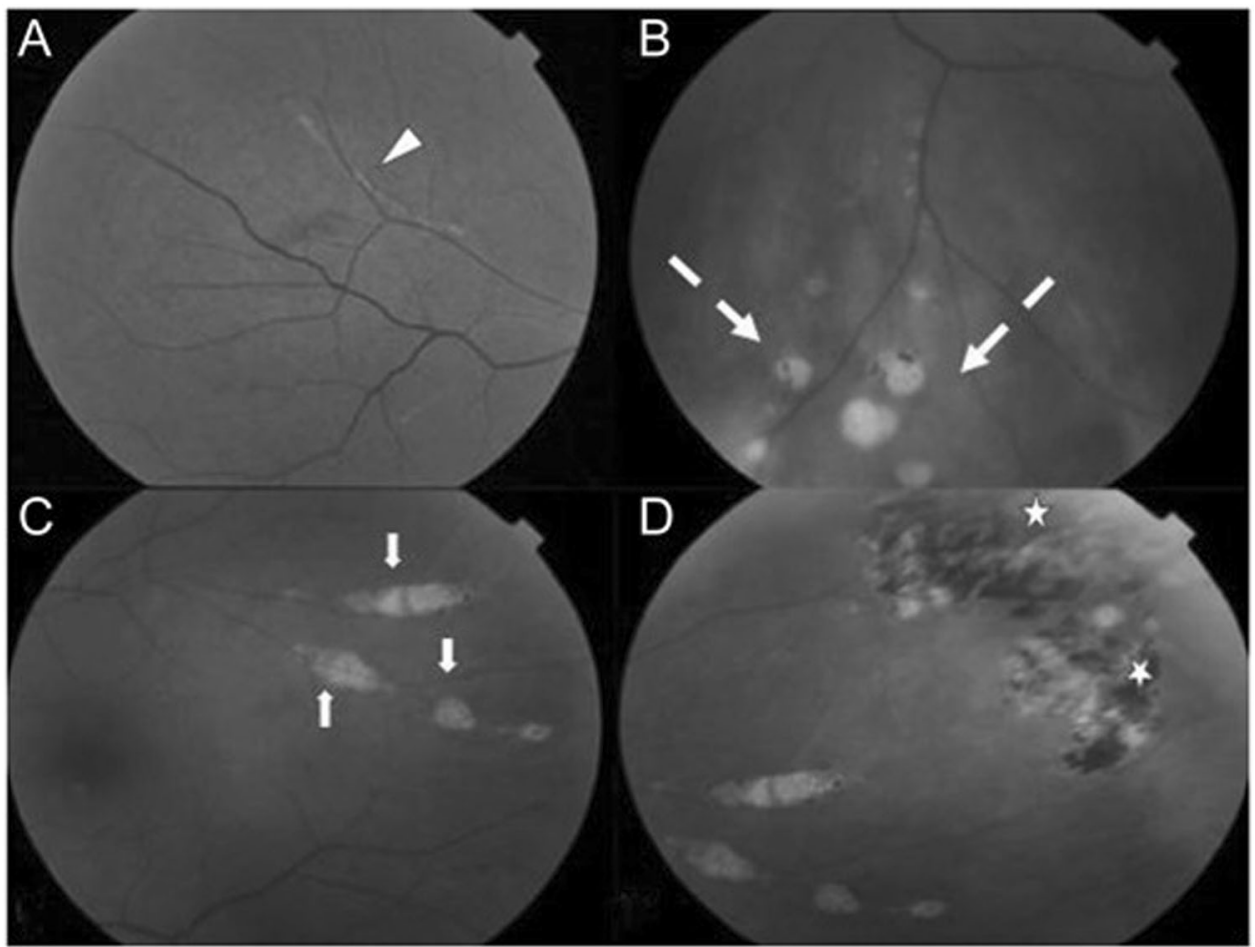


The multifocal chorioretinitis involves 10-50 deep, flat, white or yellowish lesions per eye ranging from $100-1500 \mu \mathrm{m}$ in diameter, typically arranged in a curvilinear cluster in the mid-periphery $[109,157]$. Lesions tend to self-resolve without residual pigmentation and visual acuity typically returns to baseline $[151,158-160]$. On fluorescein angiography, the active lesions are hypofluorescent initially and later hyperfluorescent. Inactive lesions have a target-like, rosette appearance [109, 161]. Chorioretinitis appears more frequently in those aged over 50 and those with diabetes mellitus [162, 163]. Other ocular manifestations include occlusive retinal vasculitis and intraretinal haemorrhages, optic neuritis, congenital chorioretinal scarring and uveitis (Fig. 4) [157, 158, 162].

Diagnosis is typically confirmed by laboratory testing using ELISA to detect IgM in serum of cerebrospinal fluid, and in limited scenarios supported by RT-PCR. There is no vaccine, treatment is supportive, with vector control as the mainstay of prevention [150].

\section{Yellow fever virus (Flaviviridae)}

The yellow fever virus (YFV) is an enveloped, positivesense, single-stranded RNA virus of the Flaviviridae family. It is an arbovirus transmitted to humans primarily through the bite of infected Aedes or Haemagogus species mosquitoes, and principally maintained by a sylvatic (jungle) transmission cycle between mosquitoes and non-human primates and mosquito-human transmission cycles in urban areas, the latter leading to outbreaks of yellow fever (YF) in human populations. Dozens of countries in both Africa and South and Central America are endemic for YF, leading to an estimated 30,000-60,000 fatalities per year [164].

The majority infected with YFV are asymptomatic or exhibit an initial phase of non-specific viral symptoms after 3-6 days (fever, myalgia, nausea and vomiting), which then resolves within days. After less than a day of resolution, $15-25 \%$ of patients develop a toxic form of the disease, with fever, a haemorrhagic diathesis and multi-organ failure (especially renal and hepatic) leading to a $50 \%$ mortality rate $[165,166]$.

A common ocular finding in the initial phase is conjunctivitis, whilst scleral icterus is often a feature of the toxic phase [109, 166]. A small number of case reports suggest other ocular manifestations, with two intensive care patients reported in Brazil noted to present with bilateral increased choroidal thickness. One subsequently develops bilateral retinal vein congestion. The other developed bilateral mid-peripheral $360^{\circ}$ detachment of the choroid and yellowish sub-retinal lesions. In another reported case, unilateral retinal oedema, macular exudates and haemorrhages were found during the convalescent stage, potentially due to immune-mediated causes [167].
There also exist case reports of ocular disorders associated with YFV vaccination, especially when the live YFV vaccine is combined with other vaccines, such as Neisseria Meningitidis, Hepatitis A/B or Typhoid. The reported complications are varied and include uveitis, unilateral optic neuropathy, evanescent white dot syndrome, multifocal choroiditis, arteriolar occlusion and even a Vogt-Koyanagi-Harada-like disease (with accompanying serous retinal detachment and choroidal thickening) [109, 168, 169]. These conditions are rarely reported and most often self-limiting with a favourable course over a few weeks with simple supportive anti-inflammatory treatment.

Diagnosis of YFV relies on PCR of blood or urine samples in the early stages, and ELISA or PRNT to detect antibodies in later stages. Treatment is mainly supportive, with a strong emphasis on prevention through public health measures and vaccination $[166,170]$.

\section{Chikungunya (Togaviridae)}

Chikungunya virus (CHIKV) is an enveloped, positivesense, single-stranded RNA virus belonging to the genus Alphavirus of the family Togaviridae. CHIKV has been identified in over 60 countries in Asia, Africa, Europe and the Americas, and several epidemics have been reported in the past 20 years commonly during monsoon season. CHIKV is principally transmitted by the bite of the mosquitoes of the Aedes genus-Aedes aegypti and Aedes albopictus are the primary vectors [171]. Transplacental transmission has been reported, without significant outcomes for mother and child [172].

CHIKV infection results primarily in an acute fever with a severe polyarthralgia predominating in the distal extremities that may persist for several weeks or months [173]. Cervical or generalized lymphadenopathy may be present, along with various mucocutaneous manifestations. Neurologic complications such as meningoencephalitis or other multi-organ failure are rare, though described in the immunocompromised and at the extremes of age. There is an overall mortality rate of 1 in 1000 , largely restricted to the elderly [174]. However, often symptoms are mild and may resolve unrecognized, or be misdiagnosed in areas where dengue occurs.

CHIKV has a variety of ocular manifestations ranging from conjunctivitis to retinitis. Photophobia, conjunctival hyperaemia and retro-orbital pain are frequent in the acute phase, and may be isolated without other ocular involvement. Anterior uveitis is the most frequently reported ocular complication (one in three ocular cases), appearing 4-12 weeks after disease onset [175]. The anterior uveitis may be either granulomatous or non-granulomatous, and may be associated with elevated intraocular pressure, or more infrequently with posterior synechiae. A Fuchs' 
uveitis phenotype of fine stellate keratic precipitates is visualised on confocal microscopy, with a diffuse distribution over the posterior cornea (Fig. 5) [109]. Although presence of CHIKV RNA has been documented by PCR
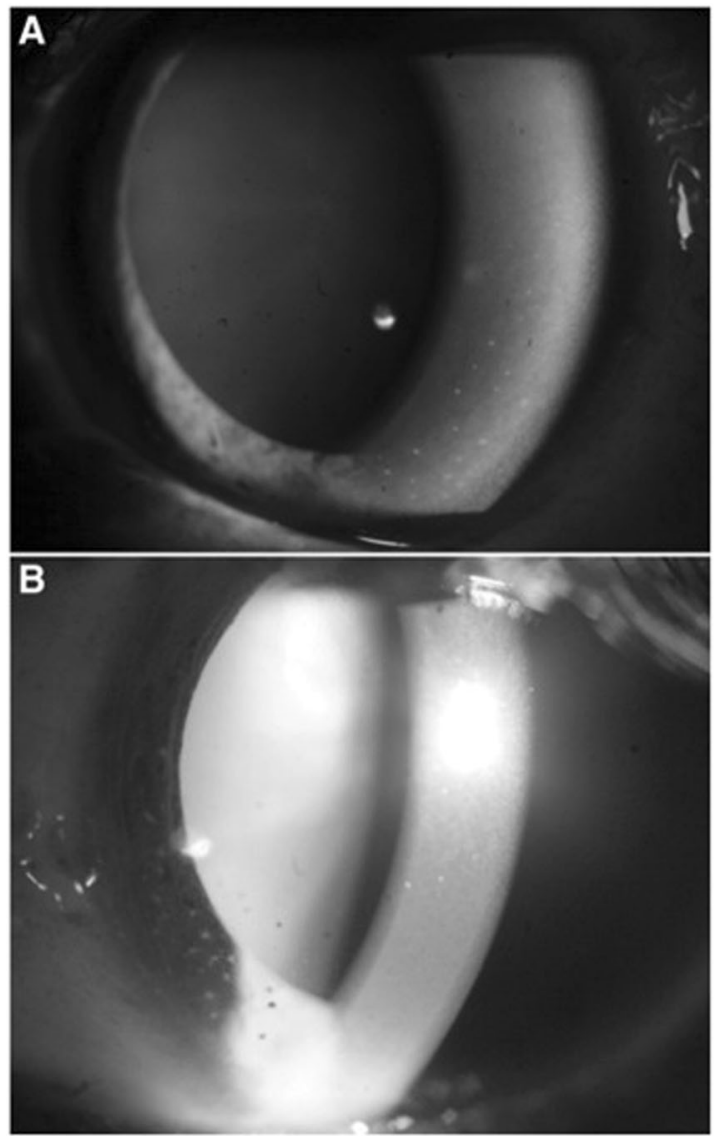

Fig. 5 Chikungunya, slit lamp anterior segment photos with $1+$ cells and $2+$ flare evident in the anterior chamber of both eyes. $A$ Pigmented keratic precipitates in the inferior cornea, $\mathbf{B}$ stellate keratic precipitates. Source: Mahendradas [233] (CC-BY Licence). analysis of aqueous samples in some patients with anterior uveitis and previous CHIKV fever, it is unclear whether this is pathogenic or merely a remnant of recent systemic illness [176]. The uveitis responds well to steroid drops and antiglaucoma drops if required, and complete resolution is achieved in $<3$ weeks [177].

Posterior uveitis often presents weeks after the acute symptoms, as retinitis, multifocal choroiditis or neuroretinitis. Neuroretinitis involves exudative haemorrhagic lesions essentially localized to the posterior pole, which can be associated with intra-/sub-retinal macular oedema [178]. The lesions are hypofluorescent in the early phases and hyperfluorescent in the late phases of fluorescein angiography (Fig. 6). The optic disc is hyperaemic, and the vitreous shows a slight inflammatory reaction. Empiric treatment with acyclovir (ineffective against RNA viruses), systemic steroids and non-steroidal anti-inflammatory drops can lead to favourable outcomes in $<2$ months, though recurrence of retinitis has been reported [177, 179, 180].

Optic neuropathy is evident in $10 \%$ of cases with ocular involvement, developing typically 1 month after disease onset [109]. In one case series of $14 \mathrm{CHIKV}+$ patients with clinical features suggestive of optic neuritis, all complained of a severe decrease in visual acuity and earlier initiation of treatment with IV methylprednisolone was associated with improved visual recovery [181]. The underlying mechanism may involve direct viral involvement (as in some cases, the onset of optic neuropathy is coincident with that of systemic signs) or an immune mechanism (as in the majority, where delayed onset, bilateral involvement and a good response to steroid treatment has been observed). Other ocular lesions have also been described: keratitis, scleritis and episcleritis, lagophthalmos and oculomotor palsies [109]. The presence of CHIKV has been demonstrated in the cornea during the viraemic phase, resulting in exclusion from corneal donation in endemic areas [182].
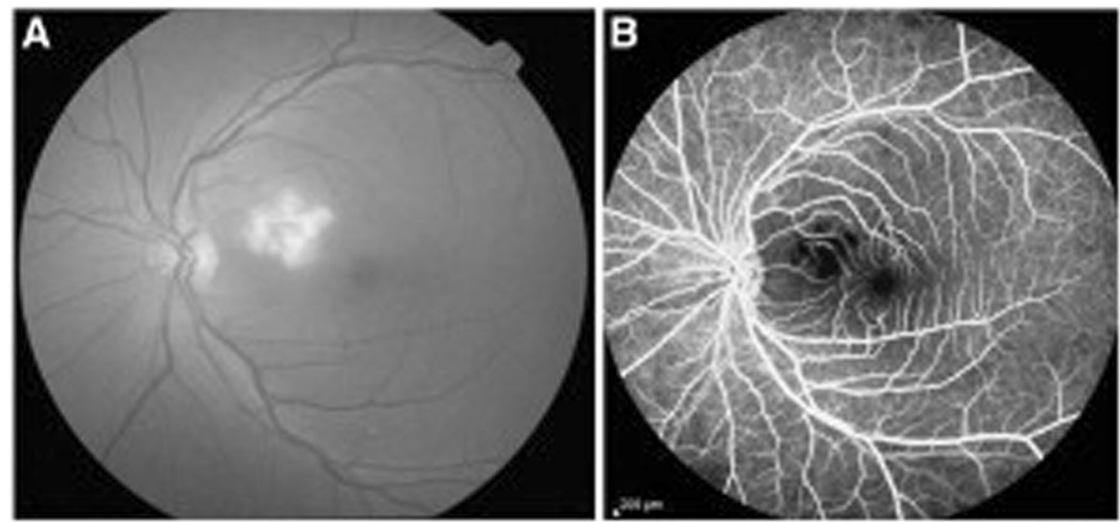

pole in early and late hypofluorescence, respectively. Source: Mahendradas [233] (CC-BY Licence).

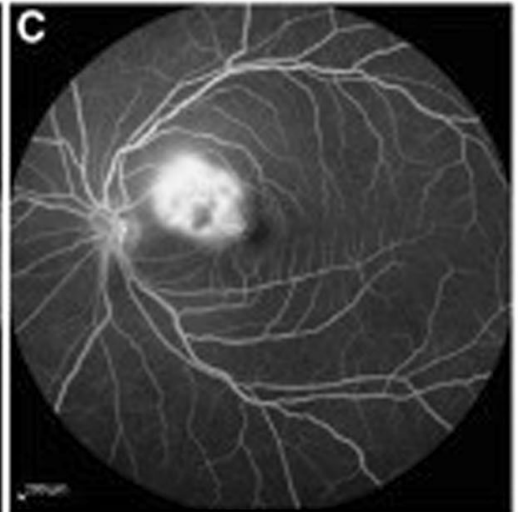

Fig. 6 Chikungunya, retinal manifestations. A Fundus image of the left eye showing confluent area of retinal whitening suggestive of retinitis. B, C Fundus fluorescein angiography showing the posterior 
Formal diagnosis of CHIKV in the initial 8 days of acute infection is done by RT-PCR or direct isolation of virus/ viral antigens, following which serological testing with ELISA is recommended [183]. Case reports highlight that RT-PCR may detect CHIKV RNA in aqueous fluid [184]. Antiviral drug and vaccine development are underway $[185,186]$.

\section{Crimean Congo* (Nairoviridae)}

Crimean-Congo haemorrhagic fever virus (CCHFV) is an enveloped, circular, negative-sense, single-stranded RNA virus in the Nairoviridae family, which causes an acute viral haemorrhagic fever. Transmission of the virus is primarily through tick bites belonging to the genus Hyalomma, which are widely distributed in Asia, Africa and Eastern Europe [187]. Transmission is also reported to occur by contact with patients or animals with a high viral load, thus posing a high risk of transmission in healthcare environments [188].

An estimated $90 \%$ of patients are oligo- or asymptomatic whilst the remaining $10 \%$ can present with the more severe form of disease described in many studies [189]. The disease manifests as sudden onset fever, myalgia and dizziness. Some develop gastro-intestinal symptoms such as vomiting and stomach pain. After 3-5 days, the haemorrhagic phase starts including bleeding (severe bruising and epistaxis), confusion and hepatomegaly. Fatality rates for hospitalised patients are documented as ranging from 9 to 50\% [190].

Only one study has formally characterised the ocular findings in CCHFV patients after previous studies reported conjunctival injection and photophobia [191]. In a case series of 19 patients, none had ocular complaints, but examination showed that $14(73.7 \%)$ had ocular abnormalities. Subconjunctival haemorrhage was present in 12 (63.2\%) patients and retinal haemorrhage was present in 7 (36.8\%) patients. Subconjunctival haemorrhage was petechial, occurring most often at the nasal quadrant and perilimbal area of both eyes. Retinal haemorrhage was dot-like or triangular at the paramacular and peripapillary area. The ocular findings did not appear to correlate with disease severity. Both types of haemorrhage had resolved completely at 1 month follow-up. The results of this small study indicate that CCHF should be considered in the differential when subconjunctival or retinal haemorrhages are seen along with fever in travellers from endemic areas [191].

Diagnosis is via serum RT-PCR in the early stages of disease or ELISA late in disease and treatment is largely supportive with some evidence that ribavirin shows some benefit $[192,193]$. After people of working age exposed to tick populations, healthcare workers are the second mostaffected group [192]. Knowledge of CCHFV may therefore help prevent nosocomial spread of the virus.

\section{Droplet}

\section{Coronavirus disease 2019 (COVID-19)* (Coronaviridae)}

Severe acute respiratory syndrome coronavirus 2 (SARS-CoV2) is an enveloped, single-stranded, positive-sense, RNA virus of the family coronaviridae [194]. SARS-CoV-2 emerged as the cause of coronavirus disease 2019 (COVID-19) in December 2019 in Wuhan, China. The subsequent pandemic of this highly transmissible virus has caused in excess of 1250,000 deaths at the time of writing, and poses an ongoing threat to global public health [195]. The main modes of transmission are respiratory droplets and direct contact [196].

COVID-19 has a viral pneumonia picture. Early symptoms occur after a median incubation period of 4 days, most commonly fever, cough and fatigue [197]. In a proportion of cases, a severe form of the disease ensues, with progression to an acute respiratory distress syndrome picture and type 1 respiratory failure. In such cases, hospitalisation is required for oxygen supplementation, and/or intubation and ventilation. Increased age and co-existing illness are associated with increased severity of disease [197].

Viral RNA has been detected in ocular secretions [7, 198]. Several reports have suggested that SARS-CoV-2 can cause a mild follicular conjunctivitis, with symptoms including conjunctival hyperaemia, chemosis, epiphora and increased secretion. Twenty-three cases have been described so far in published literature, and three cases in prepublished studies [7, 197-201]. The largest study reporting cases described conjunctival congestion in 9 of 1099 patients $(0.8 \%)$ [197]. There has been only one study showing retinal changes in COVID-19 patients [202]. Twelve COVID-19 patients examined in the study all displayed hyper-reflective changes in retinal ganglion cell and inner plexiform layers binocularly using OCT. Four patients had cotton wool spots and microhaemorrhages but no signs of intraocular inflammation. Despite OCT changes in the retina, no visual acuity nor pupillary reflex changes was found.

RT-PCR of oropharyngeal and nasopharyngeal swabs is the mainstay of testing, with other sources sampled less commonly. However, false negatives present a problem and so clinical suspicion based on symptomatology, biochemistry and imaging findings play an important role. Many clinical trials are already underway to assess potential treatment options and trials have begun for candidate vaccines [202].

\section{Influenza A H1N1 (Orthomyxoviridae)}

Influenza A H1N1 is an enveloped, negative-sense, singlestranded RNA virus of the orthomyxoviridae family. The 
subtype of Influenza A relates to cell surface glycoproteins. Influenza A undergoes continuous antigenic drift causing seasonal influenza, and sporadic antigenic shifts causing pandemics [203]. Notable pandemics include the 1918 Spanish flu and 2009 Swine flu (A(H1N1)pdm09 virus). Since then H1N1 has been identified in normal seasonal flu along with H3N2 [204]. A global average of $294,000-518,000$ respiratory deaths is associated with seasonal influenza annually [205]. The virus spreads primarily via droplet transmission though there is a role for indirect contact transmission [206]. Ex vivo cultures have also found that the $\mathrm{A}(\mathrm{H} 1 \mathrm{~N} 1) \mathrm{pdm} 09$ subtype has the ability to replicate in the human conjunctiva highlighting the conjunctiva as a potential route of infection [207].

Common symptoms include fever, cough, sore throat, coryza, myalgia, headaches and fatigue, and the disease is usually self-limiting [208]. The most common complications are viral pneumonia or secondary bacterial pneumonia. Other complications include myositis, rhabdomyolysis, myocarditis, pericarditis, encephalitis, transverse myelitis and Guillain-Barre syndrome [208]. In elderly and other high-risk individuals, deterioration of underlying cardiovascular, pulmonary and renal function may lead to irreversible changes and death [209].

Ocular involvement in influenza A virus disease is common often involving mild conjunctivitis to reports of more severe eye involvement. True prevalence of ocular manifestations is difficult to ascertain from isolated studies due to lack of thorough ophthalmoscopic examinations during influenza outbreaks, and the benign nature of the disease in most patients. This accounts for the paucity of literature and detailed retinal findings [209].

A growing body of evidence highlights the potential ocular findings in influenza A H1N1 disease. A case series of 89 patients with H1N1 infection found that acute conjunctivitis was the most common finding occurring bilaterally in $65.17 \%$ of patients and unilaterally in $12.36 \%$ patients [210]. Features of significant eyelid oedema, conjunctival hyperaemia, watery discharge and moderate chemosis with sub-tarsal follicles were evident in most patients. Ten cases of conjunctivitis were severe and two were haemorrhagic with sub-tarsal petechial haemorrhage, with such findings imaged elsewhere (Fig. 7). The condition resolved with topical NSAIDs and topical ganciclovir. Corneal involvement was present in eighteen $(20.22 \%)$ patients. Fluorescein staining revealed multiple bilateral corneal erosions that resolved by day 7 . Iridocyclitis is a much rarer reported anterior segment finding [209].

Involvement of the posterior segment is less frequent. However, there have been reports of uveal effusion syndrome, retinopathy, retinitis and optic neuritis [210-216]. Uveal effusion syndrome occurs around 2 days after flu-like symptoms. Painful red eye, reduced visual acuity, a quiet shallow anterior chamber, and swelling of the posterior chamber and vitreous cells indicative of sub-retinal exudation, are reported [210, 211]. Treatment with topical and systemic corticosteroids improved the condition in 10 days [210]. Visual defects from retinopathy usually self-resolve in 3 weeks; however, steroids may play a role in the treatment of severe cases [210, 212, 214]. One case of retinal vasculitis occurred without recovery of vision despite steroid therapy [217]. Optic neuritis has been reported with steroid therapy improving the condition [210, 216, 218]. Reports of encephalopathy associated with cortical visual loss and oculomotor palsy is also possible [219-221].

Diagnosis is made clinically except in certain scenarios where testing may influence clinical decisions, such as whether to initiate antiviral treatment, perform other diagnostic testing or to implement infection prevention and control measures [222]. Recommended diagnostic tests include rapid
A

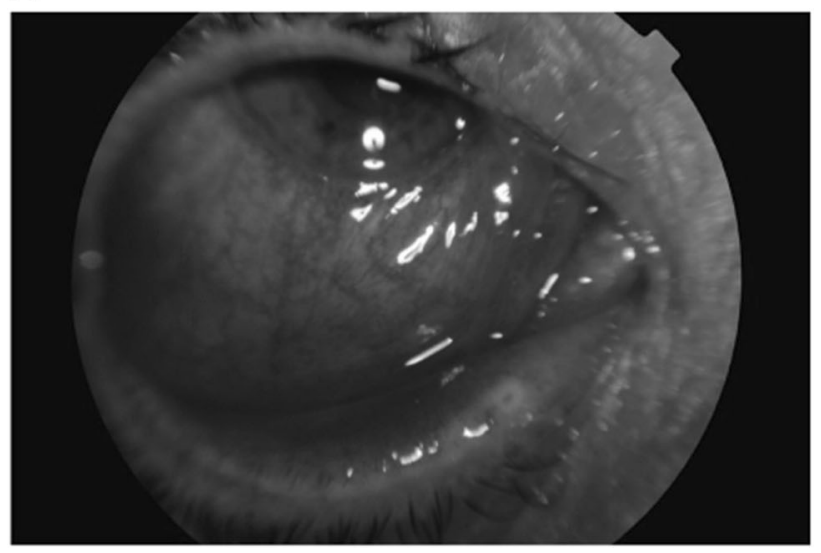

B

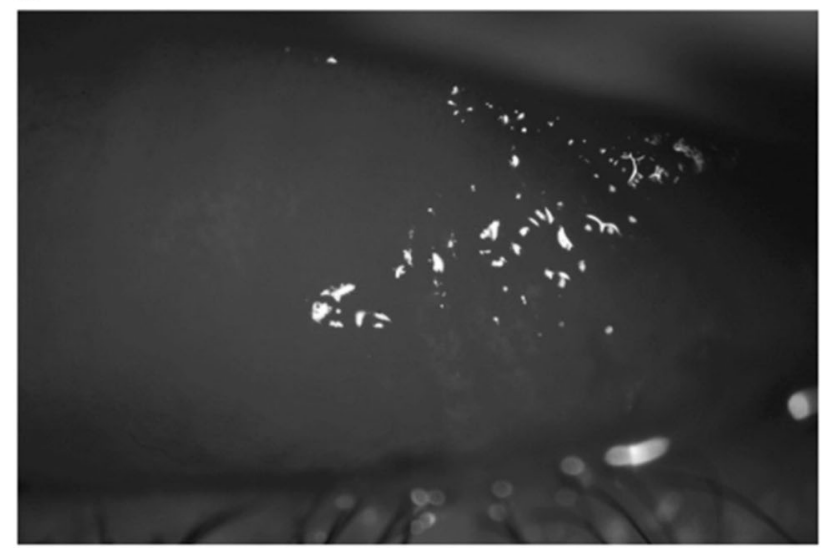

Fig. 7 Influenza virus H1N1, severe ocular cases. A Lower chemosis and severe conjunctival hyperaemia associated with significant eyelid oedema, B petechiae and significant upper sub-tarsal follicles. Source: Lopez-Pratz [234] (CC-BY Licence). 
molecular assays for outpatients and RT-PCR is recommended for hospitalised patients, using nasopharyngeal, nasal or throat swabs [223]. Awareness of ocular symptoms in influenza A virus infection may facilitate early intervention with steroids, antiviral drugs and topical treatments to prevent long-term visual damage in severe cases of H1N1. Both strains of seasonal influenza $\mathrm{H} 1 \mathrm{~N} 1$ and $\mathrm{H} 3 \mathrm{~N} 2$ are targeted in the annual influenza vaccinations [200, 201].

\section{Prevention and treatment}

These emerging viruses pose a major public health risk due to their known pandemic potential and/or insufficient counter measures. Notably, these pathogens are all RNA viruses, whose error prone RNA-dependent RNA polymerase enzymes result in inherently high mutability and capacity for host immune evasion, which may underlie their pandemic potential [224]. Continued discovery and development of new antiviral medications and vaccines are a research priority for global health, particularly as new pathogens periodically emerge and old ones evolve to evade current therapeutic agents. For the viruses discussed in this review, the availability of approved antiviral therapies and vaccines is limited (with approval only for influenza A H1N1 and Ebola vaccines); however, a number is currently under development.

In the absence of specific antiviral drugs or immunisation, precautionary strategies are the mainstay for curbing transmission. These include vector control and exposure limitation, screening and prophylaxis of exposed individuals, isolation of infected individuals and potential contacts, precautions depending on transmission route, and both personal and environmental hygiene and decontamination. Strategies for pandemic preparedness also need to be capable of mitigating risks posed by yet to emerge, unknown viruses, as reflected by inclusion of "Disease X" on WHO's shortlist of blueprint priority diseases.

Many of these viruses confer potential risk to eye care providers. Isolation of viral RNA from ocular secretions has been confirmed in humans for Ebola, Marburg, Zika, Chikungunya, COVID and influenza A H1N1, as well as in animal models of LF [7, 20, 21, 30, 118, 119, 184, 198, 207, 225, 226]. This possibility remains to be further investigated for Nipah, RVF, Dengue, West Nile and Crimean Congo virus. Together, these highlight the need for extra precautions during ophthalmic procedures in certain cases, along with advisory eye protection to limit contagion. Eye specialists are at particular risk due to the close proximity during eye examination and the potential for 'air puff' tonometry to generate droplets or aerosols [227]. General precautions in ophthalmic practice includes installation of transparent shields on slit-lamps, disinfection of surfaces and instruments after each use, donning of protective equipment, appropriate triaging and implementation of telemedicine where appropriate [228, 229]. Given the variations in practice patterns, practitioners should heed their respective best-practice guidelines for infection control.

\section{Summary}

The threat of emerging viral disease has been made all the more clear in the midst of the current COVID-19 pandemic. Further, the possibility that a yet unknown pathogen could cause a future epidemic has also been acknowledged by the WHO on their shortlist of blueprint priority diseases as 'Disease X'. It has been estimated that there are 1.67 million unknown viruses circulating in animal reservoirs and there remains the potential for them to evolve and transmit to humans [230]. It is interesting that the majority of new 'threats' have ocular manifestations.

Ophthalmologists should therefore be mindful of the variation of presentations of eye diseases in this context. The COVID-19 pandemic and studies of other viral diseases highlight that globalisation and modernisation play a significant role in the spread of viral disease and consequently returning travellers could present with manifestations of both current known and novel viral diseases. An awareness of the ocular manifestations of emerging viral diseases can therefore enable eye specialists to facilitate swift diagnosis, improve clinical outcomes and contribute to wider public health efforts during outbreaks.

Author contributions AV and RP contributed equally to conceptualising and writing the manuscript. SG and TR assisted with writing the manuscript. AS and $\mathrm{PH}$ provided expert feedback and suggested revisions to the manuscript.

\section{Compliance with ethical standards}

Conflict of interest The authors declare that they have no conflict of interest.

Publisher's note Springer Nature remains neutral with regard to jurisdictional claims in published maps and institutional affiliations.

Open Access This article is licensed under a Creative Commons Attribution 4.0 International License, which permits use, sharing, adaptation, distribution and reproduction in any medium or format, as long as you give appropriate credit to the original author(s) and the source, provide a link to the Creative Commons license, and indicate if changes were made. The images or other third party material in this article are included in the article's Creative Commons license, unless indicated otherwise in a credit line to the material. If material is not included in the article's Creative Commons license and your intended use is not permitted by statutory regulation or exceeds the permitted use, you will need to obtain permission directly from the copyright holder. To view a copy of this license, visit http://creativecommons. org/licenses/by/4.0/. 


\section{References}

1. World Health Organization, Regional Office for South-East Asia. A brief guide to emerging infectious diseases and zoonoses. WHO Regional Office for South-East Asia; 2014.

2. G. P. M. Board, World Health Organization. A world at risk: annual report on global preparedness for health emergencies. Geneva: G. P. M. Board, World Health Organization; 2019.

3. Sharma S. Diagnosis of infectious diseases of the eye. Eye Lond Engl. 2012;26:177-84.

4. Shantha JG, Crozier I, Yeh S. An update on ocular complications of Ebola virus disease. Curr Opin Ophthalmol. 2017;28:600-6.

5. Agrawal R, Oo HH, Balne PK, Ng L, Tong L, Leo YS. Zika Virus and the Eye. Ocul Immunol Inflamm. 2018;26:654-9. https://doi.org/10.1080/09273948.2017.1294184.

6. Yip VC, Sanjay S, Koh YT. Ophthalmic complications of dengue fever: a systematic review. Ophthalmol Ther. 2012;1:2. https://doi.org/10.1007/s40123-012-0002-z.

7. Wu P, Duan F, Luo C, Liu Q, Qu X, Liang L, et al. Characteristics of ocular findings of patients with coronavirus disease 2019 (COVID-19) in Hubei Province, China. JAMA Ophthalmol. 2020;138:575-8. https://doi.org/10.1001/jamaophthalmol. 2020.1291.

8. World Health Organisation. Prioritizing diseases for research and development in emergency contexts. 2021. https://www.who. int/activities/prioritizing-diseases-for-research-and-developmentin-emergency-contexts. Accessed 18 Jan 2021.

9. World Health Organisation. Ebola virus disease. 2020. https://www.who.int/news-room/fact-sheets/detail/ebola-virusdisease.

10. Jacob ST, Crozier I, Fischer WA 2nd, Hewlett A, Kraft CS, Vega MA, et al. Ebola virus disease. Nat Rev Dis Primers. 2020;6:13. https://doi.org/10.1038/s41572-020-0147-3.

11. Tiffany A, Vetter P, Mattia J, Dayer JA, Bartsch M, Kasztura M, et al. Ebola virus disease complications as experienced by survivors in Sierra Leone. Clin Infect Dis. 2016;62:1360-6. https:// doi.org/10.1093/cid/ciw158.

12. Yeh S, Shantha JG, Hayek B, Crozier I, Smith JR. Clinical manifestations and pathogenesis of Uveitis in Ebola virus disease survivors. Ocul Immunol Inflamm. 2018;26:1128-34.

13. Kibadi K, Mupapa K, Kuvula K, Massamba M, Ndaberey D, Muyembe-Tamfum JJ, et al. Late ophthalmologic manifestations in survivors of the 1995 Ebola virus epidemic in Kikwit, Democratic Republic of the Congo. J Infect Dis. 1999;179(Suppl 1):S13-4. https://doi.org/10.1086/514288.

14. Mattia JG, Vandy MJ, Chang JC, Platt DE, Dierberg K, Bausch DG, et al. Early clinical sequelae of Ebola virus disease in Sierra Leone: a cross-sectional study. Lancet Infect Dis. 2016;16:331-8. https://doi.org/10.1016/S1473-3099(15)004892.

15. Hereth-Hebert E, Bah MO, Etard JF, Sow MS, Resnikoff S, Fardeau C, et al. Ocular complications in survivors of the Ebola outbreak in Guinea. Am J Ophthalmol. 2017;175:114-21. https://doi.org/10.1016/j.ajo.2016.12.005.

16. Shantha JG, Crozier I, Hayek BR, Bruce BB, Gargu C, Brown J, et al. Ophthalmic Manifestations and causes of vision impairment in Ebola virus disease survivors in Monrovia, Liberia. Ophthalmology. 2017;124:170-7. https://doi.org/10.1016/j. ophtha.2016.10.011.

17. Chancellor JR, Padmanabhan SP, Greenough TC, Sacra R, Ellison RT 3rd, Madoff LC, et al. Uveitis and systemic inflammatory markers in convalescent phase of Ebola virus disease. Emerg Infect Dis. 2016;22:295-7. https://doi.org/10.3201/ eid2202.151416.
18. Steptoe PJ, Momorie F, Fornah AD, Komba SP, Emsley E, Scott JT, et al. Multimodal imaging and spatial analysis of ebola retinal lesions in 14 survivors of Ebola virus disease. JAMA Ophthalmol. 2018;136:689-93. https://doi.org/10.1001/jamaophthalmol. 2018.1248.

19. REVAIL III Study Group, Sneller MC, Reilly C, Badio M, Bishop RJ, Eghrari AO, et al. A longitudinal study of Ebola Sequelae in Liberia. N Engl J Med. 2019;380:924-34. https:// doi.org/10.1056/NEJMoa1805435.

20. Varkey JB, Shantha JG, Crozier I, Kraft CS, Lyon GM, Mehta $\mathrm{AK}$, et al. Persistence of Ebola virus in ocular fluid during convalescence. N Engl J Med. 2015;372:2423-7. https://doi.org/ 10.1056/NEJMoa1500306.

21. Shantha JG, Mattia JG, Goba A, Barnes KG, Ebrahim FK, Kraft $\mathrm{CS}$, et al. Ebola virus persistence in ocular tissues and fluids (EVICT) study: reverse transcription-polymerase chain reaction and cataract surgery outcomes of Ebola survivors in Sierra Leone. EBioMedicine. 2018;30:217-24. https://doi.org/10.1016/ j.ebiom.2018.03.020.

22. Shantha JG, Hayek BR, Crozier I, Gargu C, Dolo R, Brown J, et al. Development of a screening eye clinic for Ebola virus disease survivors: lessons learned and rapid implementation at ELWA Hospital in Monrovia, Liberia 2015. PLoS Negl Trop Dis. 2019;13:e007209. https://doi.org/10.1371/journal.pntd. 0007209.

23. Mulangu S, Dodd LE, Davey RT Jr, Tshiani Mbaya O, Proschan M, Mukadi D, et al. A randomized, controlled trial of Ebola virus disease therapeutics. N Engl J Med. 2019;381:2293-303. https:// doi.org/10.1056/NEJMoa1910993.

24. Henao-Restrepo AM, Longini IM, Egger M, Dean NE, Edmunds WJ, Camacho A, et al. Efficacy and effectiveness of an rVSVvectored vaccine expressing Ebola surface glycoprotein: interim results from the Guinea ring vaccination cluster-randomised trial. Lancet. 2015;386:857-66. https://doi.org/10.1016/S0140-6736 (15)61117-5.

25. Pigott DM, Golding N, Mylne A, Huang Z, Weiss DJ, Brady OJ, et al. Mapping the zoonotic niche of Marburg virus disease in Africa. Trans R Soc Trop Med Hyg. 2015;109:366-78. https:// doi.org/10.1093/trstmh/trv024.

26. Brainard J, Hooper L, Pond K, Edmunds K, Hunter PR. Risk factors for transmission of Ebola or Marburg virus disease: a systematic review and meta-analysis. Int $\mathrm{J}$ Epidemiol. 2016;45:102-16.

27. World Health Organisation. Marburg virus disease. 2018. https://www.who.int/news-room/fact-sheets/detail/marburgvirus-disease.

28. CDC. Marburg Hemorrhagic Fever (Marburg HF) I CDC; 2019. https://www.cdc.gov/vhf/marburg/index.html.

29. Gear JS, Cassel GA, Gear AJ, Trappler B, Clausen L, Meyers $\mathrm{AM}$, et al. Outbreake of Marburg virus disease in Johannesburg. Br Med J. 1975;4:489-93. https://doi.org/10.1136/bmj.4.5995. 489.

30. Kuming BS, Kokoris N. Uveal involvement in Marburg virus disease. Br J Ophthalmol. 1977;61:265-6.

31. Cooper TK, Sword J, Johnson JC, Bonilla A, Hart R, Liu DX, et al. New insights into Marburg virus disease pathogenesis in the Rhesus Macaque model. J Infect Dis. 2018;218(suppl_5): S423-33. https://doi.org/10.1093/infdis/jiy367.

32. BMJ Best Practice. Marburg virus infection-symptoms, diagnosis and treatment. https://bestpractice.bmj.com/topics/en-gb/ 1615.

33. Ebola and Marburg virus disease epidemics: preparedness, alert, control, and evaluation. Interim manual version 1.2 World Health Organization. WHO reference number: WHO/HSE/PED/ CED/2014.05 August 2014. https://apps.who.int/iris/bitstream/ha 
ndle/10665/130160/WHO_HSE_PED_CED_2014.05_eng.pdf? sequence $=1$.

34. Schirmer EC, Wyatt LS, Yamanishi K, Rodriguez WJ, Frenkel N. Differentiation between two distinct classes of viruses now classified as human herpesvirus 6. Proc Natl Acad Sci USA. 1991;88:5922-6.

35. Campadelli-Fiume G, Mirandola P, Menotti L. Human herpesvirus 6: an emerging pathogen. Emerg Infect Dis J. 1999;5. https://doi.org/10.3201/eid0503.990306.

36. Sugita S, Shimizu N, Watanabe K, Ogawa M, Maruyama K, Usui N, et al. Virological analysis in patients with human herpes virus 6-associated ocular inflammatory disorders. Investig Ophthalmol Vis Sci. 2012;53:4692-8. https://doi.org/10.1167/iovs. 12-10095.

37. Yamanishi K, Okuno T, Shiraki K, Takahashi M, Kondo T, Asano $\mathrm{Y}$, et al. Identification of human herpesvirus- 6 as a causal agent for exanthem subitum. Lancet. 1988;1:1065-7. https://doi. org/10.1016/s0140.6736(88)91893-4.

38. Qavi HB, Green MT, Pearson G, Ablashi D. Possible role of HHV-6 in the development of AIDS retinitis. Vivo Athens Greece. 1994;8:527-32.

39. Reux I, Fillet AM, Agut H, Katlama C, Hauw JJ, LeHoang P. In situ detection of human herpesvirus 6 in retinitis associated with acquired immunodeficiency syndrome. Am J Ophthalmol. 1992;114:375-7. https://doi.org/10.1016/s0002-9394(14)718148.

40. Qavi HB, Green MT, SeGall GK, Lewis DE, Hollinger FB. Transcriptional activity of HIV-1 and HHV-6 in retinal lesions from AIDS patients. Invest Ophthalmol Vis Sci. 1992;33:2759-67.

41. Fillet AM, Reux I, Joberty C, Fournier JG, Hauw JJ, Le Hoang $P$, et al. Detection of human herpes virus 6 in AIDS-associated retinitis by means of in situ hybridization, polymerase chain reaction and immunohistochemistry. J Med Virol. 1996;49:289-95. https://doi.org/10.1002/(SICI)1096-9071 (199608)49:4<289::AID-JMV6>3.0.CO;2-\#.

42. de Groot-Mijnes JD, de Visser L, Zuurveen S, Martinus RA, Völker R, ten Dam-van Loon NH, et al. Identification of new pathogens in the intraocular fluid of patients with uveitis. Am J Ophthalmol. 2010;150:628-36. https://doi.org/10.1016/j.ajo. 2010.05.015.

43. Cohen JI, Fahle G, Kemp MA, Apakupakul K, Margolis TP. Human herpesvirus 6-A, 6-B, and 7 in vitreous fluid samples. J Med Virol. 2010;82:996-9.

44. Sugita S, Shimizu N, Kawaguchi T, Akao N, Morio T, Mochizuki M. Identification of human herpesvirus 6 in a patient with severe unilateral panuveitis. Arch Ophthalmol. 2007;125:1426-7. https://doi.org/10.1001/archopht.125.10. 1426.

45. Maslin J, Bigaillon C, Froussard F, Enouf V, Nicand E. Acute bilateral uveitis associated with an active human herpesvirus- 6 infection. J Infect. 2007;54:e237-40.

46. Ogata N, Koike N, Yoshikawa T, Takahashi K. Human herpesvirus 6-associated uveitis with optic neuritis diagnosed by multiplex PCR. Jpn J Ophthalmol. 2011;55:502-5.

47. Méchaï F, Boutolleau D, Manceron V, Gasnault J, Quertainmont Y, Brosseau JP, et al. Human herpesvirus 6-associated retrobulbar optic neuritis in an HIV-infected patient: response to antiherpesvirus therapy and long-term outcome. J Med Virol. 2007;79:931-4. https://doi.org/10.1002/jmv.20833.

48. Moschettini D, Franceschini R, Vaccaro NM, Cermelli C, Pezzini F, Balestrieri M, et al. Human herpesvirus-6B active infection associated with relapsing bilateral anterior optic neuritis. J Clin Virol. 2006;37:244-7. https://doi.org/10.1016/j.jcv.2006. 08.018 .
49. Hino Y, Doki N, Sekiya N, Takaki Y, Ohashi K. Optic neuritis as an initial manifestation of human herpesvirus 6 reactivation after unrelated bone marrow transplantation. $\mathrm{Br} \mathrm{J}$ Haematol. 2016;172:654.

50. Arao Y, Soushi S, Sato Y, Moriishi E, Ando Y, Yamada M, et al. Infection of a human retinal pigment epithelial cell line with human herpesvirus 6 variant A. J Med Virol. 1997;53:105-10.

51. Humar A, Malkan G, Moussa G, Greig P, Levy G, Mazzulli T. Human herpesvirus-6is associated with cytomegalovirus reactivation in liver transplant recipients. $J$ Infect Dis. 2000;181:1450-3. https://doi.org/10.1086/315391.

52. Okuno T, Hooper LC, Ursea R, Smith J, Nussenblatt R, Hooks $\mathrm{JJ}$, et al. Role of human herpes virus 6 in corneal inflammation alone or with human herpesviruses. Cornea. 2011;30:204-7. https://doi.org/10.1097/ICO.0b013e3181e2e9be.

53. Boto-de-los-Bueis A, Romero Gómez MP, del Hierro Zarzuelo A, Sanchez EG, Mediero S, Noval S. Recurrent ocular surface inflammation associated with human herpesvirus 6 infection. Eye Contact Lens. 2015;41:e11-3. https://doi.org/10.1097/ICL. 0b013e3182a70a1b.

54. HHV-6 Foundation. HHV-6A/B testing overview on testing for HHV-6 infection. 2021. https://hhv-6foundation.org/patients/ hhv-6-testing-for-patients.

55. Dewhurst S. Human herpesvirus type 6 and human herpesvirus type 7 infections of the central nervous system. Herpes J IHMF. 2004;11 Suppl 2:105A-11A.

56. De Bolle L, Naesens L, De Clercq E. Update on human herpesvirus 6 biology, clinical features, and therapy. Clin Microbiol Rev. 2005;18:217-45.

57. World Health Organisation. Lassa fever. 2017. https://www.who. $\mathrm{int} /$ news-room/fact-sheets/detail/lassa-fever.

58. White HA. Lassa fever. A study of 23 hospital cases. Trans R Soc Trop Med Hyg. 1972;66:390-401.

59. McCormick JB, King IJ, Webb PA, Johnson KM, O'Sullivan R, Smith ES, et al. A case-control study of the clinical diagnosis and course of Lassa fever. J Infect Dis. 1987;155:445-55. https://doi. org/10.1093/infdis/155.3.445.

60. Jahrling PB, Hesse RA, Eddy GA, Johnson KM, Callis RT, Stephen EL. Lassa virus infection of rhesus monkeys: pathogenesis and treatment with ribavirin. $\mathbf{J}$ Infect Dis. 1980;141:580-9. https://doi.org/10.1093/infdis/141.5.580.

61. Eberhardt KA, Mischlinger J, Jordan S, Groger M, Günther S, Ramharter M. Ribavirin for the treatment of Lassa fever: a systematic review and meta-analysis. Int $\mathrm{J}$ Infect Dis. 2019;87:15-20. https://doi.org/10.1016/j.ijid.2019.07.015.

62. McCormick JB, King IJ, Webb PA, Scribner CL, Craven RB, Johnson KM, et al. Lassa fever. Effective therapy with ribavirin. N Engl J Med. 1986;314:20-6. https://doi.org/10.1056/ NEJM198601023140104.

63. Luby SP. The pandemic potential of Nipah virus. Antivir Res. 2013;100:38-43.

64. Lim CC, Lee WL, Leo YS, Lee KE, Chan KP, Ling AE, et al. Late clinical and magnetic resonance imaging follow up of Nipah virus infection. J Neurol Neurosurg Psychiatry. 2003;74:131-3. https://doi.org/10.1136/jnnp.74.1.131.

65. Goh KJ, Tan CT, Chew NK, Tan PS, Kamarulzaman A, Sarji SA, et al. Clinical features of Nipah virus encephalitis among pig farmers in Malaysia. N Engl J Med. 2000;342:1229-35. https:// doi.org/10.1056/NEJM200004273421701.

66. Mire CE, Satterfield BA, Geisbert JB, Agans KN, Borisevich V, Yan L, et al. Pathogenic differences between Nipah virus Bangladesh and Malaysia strains in primates: implications for antibody therapy. Sci Rep. 2016;6:30916. https://doi.org/10.1038/ srep30916. 
67. Singh RK, Dhama K, Chakraborty S, Tiwari R, Natesan S, Khandia R, et al. Nipah virus: epidemiology, pathology, immunobiology and advances in diagnosis, vaccine designing and control strategies-a comprehensive review. Vet Q. 2019;39:26-55. https://doi.org/10.1080/01652176.2019. 1580827.

68. Chong HT, Kunjapan SR, Thayaparan T, Tong J, Petharunam V, Jusoh MR, et al. Nipah encephalitis outbreak in Malaysia, clinical features in patients from Seremban. Can J Neurol Sci. 2002;29:83-7. https://doi.org/10.1017/s0317167100001785.

69. Ikegami T. Molecular biology and genetic diversity of Rift Valley fever virus. Antivir Res. 2012;95:293-310.

70. Linthicum KJ, Britch SC, Anyamba A. Rift Valley fever: an emerging mosquito-borne disease. Annu Rev Entomol. 2016;61:395-415.

71. World Health Organisation. Rift Valley fever. 2018. https://www.who.int/news-room/fact-sheets/detail/rift-valleyfever.

72. Dar O, McIntyre S, Hogarth S, Heymann D. Rift Valley fever and a new paradigm of research and development for zoonotic disease control. Emerg Infect Dis. 2013;19:189-93.

73. Hartman A. Rift Valley fever. Clin Lab Med. 2017;37:285-301.

74. Al-Hazmi M, Ayoola EA, Abdurahman M, Banzal S, Ashraf J, El-Bushra A, et al. Epidemic Rift Valley fever in Saudi Arabia: a clinical study of severe illness in humans. Clin Infect Dis. 2003;36:245-52. https://doi.org/10.1086/345671.

75. Al-Hazmi A, Al-Rajhi AA, Abboud EB, Ayoola EA, Al-Hazmi M, Saadi R, et al. Ocular complications of Rift Valley fever outbreak in Saudi Arabia. Ophthalmology. 2005;112:313-8. https://doi.org/10.1016/j.ophtha.2004.09.018.

76. Siam AL, Meegan JM, Gharbawi KF. Rift Valley fever ocular manifestations: observations during the 1977 epidemic in Egypt. Br J Ophthalmol 1980;64:366-74.

77. LaBeaud AD, Muiruri S, Sutherland LJ, Dahir S, Gildengorin G, Morrill J, et al. Postepidemic analysis of Rift Valley fever virus transmission in northeastern Kenya: a village cohort study. PLoS Negl Trop Dis. 2011;5:e1265. https://doi.org/10.1371/journal. pntd.0001265.

78. Gear J, De Meillon B, Measroch V, Davis DHS, Harwin H. Rift Valley fever in South Africa. 2. The occurrence of human cases in the Orange Free State, the North-Western Cape Province, the Western and Southern Transvaal. B. Field and laboratory investigation. S Afr Med J Suid-Afr Tydskr Vir Geneeskd. 1951;25:908-12.

79. Freed I. Rift Valley fever in man, complicated by retinal changes and loss of vision. S Afr Med J Suid-Afr Tydskr Vir Geneeskd. 1951;25:930-2.

80. Meegan JM, Watten RH, Laughlin LW. Clinical experience with Rift Valley fever in humans during the 1977 Egyptian epizootic. Proc. Rift Val. Fever Workshop. 1981.

81. Ayoub M, Barhoma G, Zaghlol I. Ocular manifestations of Rift Valley fever. Bull Ophthalmol Soc Egypt. 1978;71:125-33.

82. Deutman AF, Klomp HJ. Rift Valley fever retinitis. Am J Ophthalmol. 1981;92:38-42.

83. Javelle E, Lesueur A, Pommier de Santi V, de Laval F, Lefebvre $\mathrm{T}$, Holweck G, et al. The challenging management of Rift Valley fever in humans: literature review of the clinical disease and algorithm proposal. Ann Clin Microbiol Antimicrob. 2020;19:4. https://doi.org/10.1186/s12941-020-0346-5.

84. Enría D, Padula P, Segura EL, Pini N, Edelstein A, Posse CR, et al. Hantavirus pulmonary syndrome in Argentina. Possibility of person to person transmission. Medicina. 1996;56:709-11.

85. Wells RM, Sosa Estani S, Yadon ZE, Enria D, Padula P, Pini N, et al. An unusual hantavirus outbreak in southern Argentina: person-to-person transmission? Hantavirus Pulmonary Syndrome
Study Group for Patagonia. Emerg Infect Dis. 1997;3:171-4. https://doi.org/10.3201/eid0302.970210.

86. Krüger DH, Schönrich G, Klempa B. Human pathogenic hantaviruses and prevention of infection. Hum Vaccin. 2011;7:685-93.

87. Jiang H, Zheng X, Wang L, Du H, Wang P, Bai X. Hantavirus infection: a global zoonotic challenge. Virol Sin. 2017;32:32-43. https://doi.org/10.1007/s12250-016-3899-x.

88. Avšič-Županc T, Saksida A, Korva M. Hantavirus infections. Clin Microbiol Infect Publ Eur Soc Clin Microbiol Infect Dis. 2019;21S:e6-e16.

89. Kontkanen M, Puustjärvi T, Lähdevirta J. Myopic shift and its mechanism in nephropathia epidemica or Puumala virus infection. Br J Ophthalmol. 1994;78:903-6.

90. Theiler G, Langer-Wegscheider B, Zollner-Schwetz I, Valentin T, Hönigl M, Schnedl W, et al. Blurred vision and myopic shift in Puumala virus infections are independent of disease severity. Clin Microbiol Infect. 2012;18:E435-7. https://doi.org/10.1111/ j.1469-0691.2012.03997.x.

91. Tilkin C, Bonnet S. [Acute myopic shift call sign of hantavirus infection]. Rev Med Liege. 2018;73:425-7.

92. Baillieul A, Le TL, Rouland J-F. Acute angle-closure glaucoma with choroidal effusion revealing a hantavirus infection: description of ultrasound biomicroscopy imagery and optical coherence tomography Visante. Eur J Ophthalmol. 2019. https:// doi.org/10.1177/1120672119858895.

93. Hautala N, Kauma H, Vapalahti O, Mähönen SM, Vainio O, Vaheri A, et al. Prospective study on ocular findings in acute Puumala hantavirus infection in hospitalised patients. Br J Ophthalmol. 2011;95:559-62. https://doi.org/10.1136/bjo.2010.185413.

94. Mehta S, Jiandani P. Ocular features of hantavirus infection. Indian J Ophthalmol. 2007;55:378-80.

95. Cao Y, Zhao X, Yi J, Tang R, Lei S. Hantavirus retinitis and concurrent hemorrhagic fever with renal syndrome. Can J Ophthalmol. 2017;52:e41-4.

96. Liu R, Ma H, Shu J, Zhang Q, Han M, Liu Z, et al. Vaccines and therapeutics against hantaviruses. Front Microbiol. 2020;10:2989. https://doi.org/10.3389/fmicb.2019.02989.

97. Guzman MG, Gubler DJ, Izquierdo A, Martinez E, Halstead SB. Dengue infection. Nat Rev Dis Prim. 2016;2:1-25.

98. Organization, WH. Dengue guidelines for diagnosis, treatment, prevention and control: new edition. World Health Organization; 2009.

99. Bhatt S, Gething PW, Brady OJ, Messina JP, Farlow AW, Moyes CL, et al. The global distribution and burden of dengue. Nature. 2013;496:504-7. https://doi.org/10.1038/nature12060.

100. Beatty M, Letson G, Margolis HS. Estimating the global burden of dengue. Am J Trop Med Hyg. 2009;81.

101. World Health Organization. Global strategy for dengue prevention and control 2012-2020. https://apps.who.int/iris/handle/ $10665 / 75303$.

102. Gubler DJ. Dengue, urbanization and globalization: the unholy trinity of the 21st century. Trop Med Health. 2011;39:3-11.

103. Kapoor HK, Bhai S, John M, Xavier J. Ocular manifestations of dengue fever in an East Indian epidemic. Can J Ophthalmol. 2006;41:741-6.

104. Gupta A, Srinivasan R, Setia S, Soundravally R, Pandian DG. Uveitis following dengue fever. Eye. 2009;23:873-6.

105. Somkijrungroj T, Kongwattananon W. Ocular manifestations of dengue. Curr Opin Ophthalmol. 2019;30:500-5.

106. Su DH, Bacsal K, Chee SP, Flores JV, Lim WK, Cheng BC, et al. Prevalence of dengue maculopathy in patients hospitalized for dengue fever. Ophthalmology. 2007;114:1743-7. https://doi. org/10.1016/j.ophtha.2007.03.054.

107. Chee E, Sims JL, Jap A, Tan BH, Oh H, Chee SP. Comparison of prevalence of dengue maculopathy during two epidemics with 
differing predominant serotypes. Am J Ophthalmol. 2009;148:910-3. https://doi.org/10.1016/j.ajo.2009.06.030.

108. Teoh SC, Chee CK, Laude A, Goh KY, Barkham T, Ang BS, et al. Optical coherence tomography patterns as predictors of visual outcome in dengue-related maculopathy. Retina. 2010;30:390-8. https://doi.org/10.1097/IAE.0b013e3181bd2fc6.

109. Merle H, Donnio A, Jean-Charles A, Guyomarch J, Hage R, Najioullah F, et al. Ocular manifestations of emerging arboviruses: dengue fever, chikungunya, Zika virus, West Nile virus, and yellow fever. J Fr Ophtalmol. 2018;41:e235-43. https://doi. org/10.1016/j.jfo.2018.05.002.

110. Bacsal KE, Chee S-P, Cheng C-L, Flores JVP. Dengueassociated maculopathy. Arch Ophthalmol. 2007;125:501-10.

111. Tavassoli S, Carreño E, Teoh SC, Theodoropoulou S, Bailey C, Lee RW, et al. Optical coherence tomography angiography findings in dengue-related maculopathy: a case report. Ophthalmic Surg Lasers Imaging. Retina. 2016;47:1057-60. https://doi. org/10.3928/23258160-20161031-12.

112. Scherwitzl I, Mongkolsapaja J, Screaton G. Recent advances in human flavivirus vaccines. Curr Opin Virol. 2017;23:95-101.

113. Javed F, Manzoor KN, Ali M, Haq IU, Khan AA, Zaib A, et al Zika virus: what we need to know? J Basic Microbiol. 2018;58:3-16. https://doi.org/10.1002/jobm.201700398.

114. Kuno G, Chang G-JJ. Full-length sequencing and genomic characterization of Bagaza, Kedougou, and Zika viruses. Arch Virol. 2007;152:687-96.

115. de Oliveira Dias JR, Ventura CV, de Paula Freitas B, Prazeres J, Ventura LO, Bravo-Filho V, et al. Zika and the eye: pieces of a puzzle. Prog Retin Eye Res. 2018;66:85-106. https://doi.org/10. 1016/j.preteyeres.2018.04.004.

116. Marquezan MC, Ventura CV, Sheffield JS, Golden WC, Omiadze R, Belfort R Jr, et al. Ocular effects of Zika virus-a review. Surv Ophthalmol. 2018;63:166-73. https://doi.org/10. 1016/j.survophthal.2017.06.001.

117. World Health Organisation. Zika virus. 2018. https://www.who. int/news-room/fact-sheets/detail/zika-virus.

118. Sun J, Wu D, Zhong H, Guan D, Zhang H, Tan Q, et al. Presence of Zika virus in conjunctival fluid. JAMA Ophthalmol. 2016;134:1330-2. https://doi.org/10.1001/jamaophthalmol.2016. 3417 .

119. Tan JJL, Balne PK, Leo YS, Tong L, Ng LFP, Agrawal R. Persistence of Zika virus in conjunctival fluid of convalescence patients. Sci Rep. 2017;7:11194.

120. Brasil P, Pereira JP Jr, Moreira ME, Ribeiro Nogueira RM, Damasceno L, Wakimoto $M$, et al. Zika virus infection in pregnant women in Rio de Janeiro. $\mathrm{N}$ Engl $\mathrm{J}$ Med. 2016;375:2321-34. https://doi.org/10.1056/NEJMoa1602412.

121. Duffy MR, Chen TH, Hancock WT, Powers AM, Kool JL, Lanciotti RS, et al. Zika virus outbreak on Yap Island, Federated States of Micronesia. N Engl J Med. 2009;360:2536-43. https:// doi.org/10.1056/NEJMoa0805715.

122. Petersen LR, Jamieson DJ, Powers AM, Honein MA. Zika Virus. N Engl J Med 2016;374:1552-63.

123. Dirlikov E, Major CG, Mayshack M, Medina N, Matos D, Ryff $\mathrm{KR}$, et al. Guillain-Barré syndrome during ongoing Zika virus transmission-Puerto Rico, January 1-July 31, 2016. MMWR Morb Mortal Wkly Rep. 2016;65:910-4. https://doi.org/10. 15585/mmwr.mm6534e1.

124. Moore CA, Staples JE, Dobyns WB, Pessoa A, Ventura CV, Fonseca EB, et al. Characterizing the pattern of anomalies in congenital Zika syndrome for pediatric clinicians. JAMA Pediatr. 2017;171:288-95. https://doi.org/10.1001/jamapediatrics.2016. 3982.

125. Shapiro-Mendoza CK, Rice ME, Galang RR, Fulton AC, VanMaldeghem K, Prado MV, et al. Pregnancy outcomes after maternal Zika virus infection during pregnancy-U.S. Territories,
January 1, 2016-April 25, 2017. MMWR Morb Mortal Wkly Rep. 2017;66:615-21. https://doi.org/10.15585/mmwr.mm6623e1.

126. CDC. Data \& statistics on Zika and pregnancylCDC. Centers for Disease Control and Prevention; 2019. https://www.cdc.gov/ pregnancy/zika/data/index.html.

127. Wheeler AC. Development of infants with congenital Zika syndrome: what do we know and what can we expect? Pediatrics. 2018;141:S154-60.

128. Molnár Z, Kennedy S. Neurodevelopmental disorders: risks of Zika virus during the first trimester of pregnancy. Nat Rev Neurol. 2016;12:315-6.

129. Cerbino-Neto J, Mesquita EC, Souza TM, Parreira V, Wittlin BB, Durovni B, et al. Clinical manifestations of Zika virus infection, Rio de Janeiro, Brazil, 2015. Emerg Infect Dis. 2016;22:1318-20. https://doi.org/10.3201/eid2207.160375.

130. Oliver GF, Carr JM, Smith JR. Emerging infectious uveitis: Chikungunya, dengue, Zika and Ebola: a review. Clin Exp Ophthalmol. 2019;47:372-80.

131. Furtado JM, Espósito DL, Klein TM, Teixeira-Pinto T, da Fonseca BA. Uveitis associated with Zika virus infection. 2016. https://doi.org/10.1056/NEJMc1603618.

132. Fontes BM, Fontes BM. Iridociclite hipertensiva associada à infecção por Zika vírus. Arq Bras Oftalmol. 2016;79:63.

133. Merle H, Najioullah F, Chassery M, Césaire R, Hage R. Zikarelated bilateral hypertensive anterior acute uveitis. JAMA Ophthalmol. 2017;135:284-5.

134. Panday A, Sandy S, King D, Ramdeen S. A case of suspected symptomatic Zika neuroretinitis. IDCases. 2017;9:104-5.

135. Henry CR, Al-Attar L, Cruz-Chacón AM, Davis JL. Chorioretinal lesions presumed secondary to Zika virus infection in an immunocompromised adult. JAMA Ophthalmol. 2017;135:386-9.

136. Kodati S, Palmore TN, Spellman FA, Cunningham D, Weistrop B, Sen HN. Bilateral posterior uveitis associated with Zika virus infection. Lancet. 2017;389:125-6. https://doi.org/10.1016/ S0140-6736(16)32518-1.

137. Wong CW, Ng SR, Cheung CMG, Wong TY, Mathur R. Zikarelated maculopathy. Retin Cases Brief Rep. 2019;13:171-3.

138. Parke DW 3rd, Almeida DR, Albini TA, Ventura CV, Berrocal AM, Mittra RA. Serologically confirmed Zika-related unilateral acute maculopathy in an adult. Ophthalmology. 2016;123:2432-3. https://doi.org/10.1016/j.ophtha.2016.06.039.

139. Ventura CV, Maia M, Travassos SB, Martins TT, Patriota F, Nunes ME, et al. Risk factors associated with the ophthalmoscopic findings identified in infants with presumed Zika virus congenital infection. JAMA Ophthalmol. 2016;134:912-8. https://doi.org/10.1001/jamaophthalmol.2016.1784.

140. de Paula Freitas B, de Oliveira Dias JR, Prazeres J, Sacramento GA, Ko AI, Maia M, et al. Ocular findings in infants with microcephaly associated with presumed Zika virus congenital infection in Salvador, Brazil. JAMA Ophthalmol. 2016;134:529-35. https://doi.org/10.1001/jamaophthalmol.2016. 0267.

141. Ventura CV, Ventura Filho MC, Ventura LO. Ocular manifestations and visual outcome in children with congenital Zika syndrome. Top Magn Reson Imaging TMRI. 2019;28:23-7.

142. Singh PK, Guest JM, Kanwar M, Boss J, Gao N, Juzych MS, et al. Zika virus infects cells lining the blood-retinal barrier and causes chorioretinal atrophy in mouse eyes. JCI Insight. 2017;2: e92340. https://doi.org/10.1172/jci.insight.92340.

143. van den Pol AN, van den, Mao G, Yang Y, Ornaghi S, Davis JN. Zika virus targeting in the developing brain. J Neurosci. 2017;37:2161-75.

144. Fernandez MP, Parra Saad E, Ospina Martinez M, Corchuelo S, Mercado Reyes M, Herrera MJ, et al. Ocular Histopathologic features of congenital Zika syndrome. JAMA Ophthalmol. 
2017;135:1163-9. https://doi.org/10.1001/jamaophthalmol.2017. 3595.

145. de Paula Freitas B, Zin A, Ko A, Maia M, Ventura CV, Belfort R Jr. Anterior-Segment Ocular Findings and Microphthalmia in Congenital Zika Syndrome. Ophthalmology. 2017;124:1876-8. https://doi.org/10.1016/j.ophtha.2017.06.009.

146. WHO. Laboratory testing for Zika virus infection. WHO; 2016. http://www.who.int/csr/resources/publications/zika/laboratorytesting/en/.

147. Adebanjo T, Godfred-Cato S, Viens L, Fischer M, Staples JE, Kuhnert-Tallman W, et al. Update: interim guidance for the diagnosis, evaluation, and management of infants with possible congenital Zika virus infection-United States, October 2017. MMWR Morb Mortal Wkly Rep. 2017:66:1089-99 https://doi. org/10.15585/mmwr.mm6641a1.

148. Staples JE, Dziuban EJ, Fischer M, Cragan JD, Rasmussen SA, Cannon MJ, et al. Interim guidelines for the evaluation and testing of infants with possible congenital Zika virus infectionUnited States, 2016. MMWR Morb Mortal Wkly Rep. 2016;65:63-7. https://doi.org/10.15585/mmwr.mm6503e3.

149. Ventura LO, Lawrence L, Ventura CV, Dutton GN, Marinho P, Ferro PF, et al. Response to correction of refractive errors and hypoaccommodation in children with congenital Zika syndrome. J AAPOS. 2017;21:480-4.e1. https://doi.org/10.1016/j.jaapos. 2017.07.206.

150. Petersen LR, Brault AC, Nasci RS. West Nile virus: review of the literature. JAMA. 2013;310:308-15.

151. Garg S, Jampol LM. Systemic and intraocular manifestations of West Nile virus infection. Surv Ophthalmol. 2005;50:3-13.

152. World Health Organisation. West Nile virus. 2017. https://www. who.int/news-room/fact-sheets/detail/west-nile-virus.

153. Zou S, Foster GA, Dodd RY, Petersen LR, Stramer SL. West Nile fever characteristics among viremic persons identified through blood donor screening. J Infect Dis. 2010;202:1354-61.

154. Mostashari F, Bunning ML, Kitsutani PT, Singer DA, Nash D, Cooper MJ, et al. Epidemic West Nile encephalitis, New York, 1999: results of a household-based seroepidemiological survey. Lancet. 2001;358:261-4. https://doi.org/10.1016/S0140-6736 (01)05480-0.

155. Lindsey N, Staples E, Lehman J, Fischer M. Surveillance for human West Nile virus disease-United States, 1999-2008. 2010. https://www.cdc.gov/mmwr/preview/mmWrhtml/ss5902a 1.htm.

156. Burton JM, Kern RZ, Halliday W, Mikulis D, Brunton J, Fearon $M$, et al. Neurological manifestations of West Nile virus infection. Can J Neurol Sci. 2004;31:185-93. https://doi.org/10.1017/ s0317167100053828.

157. Khairallah M, Ben Yahia S, Ladjimi A, Zeghidi H, Ben Romdhane F, Besbes L, et al. Chorioretinal involvement in patients with West Nile virus infection. Ophthalmology. 2004;111:2065-70. https://doi.org/10.1016/j.ophtha.2004.03. 032.

158. Sivakumar RR, Prajna L, Arya LK, Muraly P, Shukla J, Saxena $\mathrm{D}$, et al. Molecular diagnosis and ocular imaging of West Nile virus retinitis and neuroretinitis. Ophthalmology. 2013;120:1820-6. https://doi.org/10.1016/j.ophtha.2013.02.006.

159. Koevary SB. Ocular involvement in patients infected by the West Nile virus. Optometry. 2005;76:609-12.

160. Lee JH, Agarwal A, Mahendradas P, Lee CS, Gupta V, Pavesio CE, et al. Viral posterior uveitis. Surv Ophthalmol. 2017;62:404-45. https://doi.org/10.1016/j.survophthal.2016.12.008.

161. Yahia SB, Khairallah M. Ocular manifestations of West Nile virus infection. Int J Med Sci. 2009;6:114-5.

162. Chan CK, Limstrom SA, Tarasewicz DG, Lin SG. Ocular features of west nile virus infection in North America: a study of 14 eyes. Ophthalmology. 2006;113:1539-46.
163. Khairallah M, Yahia SB, Letaief M, Attia S, Kahloun R, Jelliti B, et al. A prospective evaluation of factors associated with chorioretinitis in patients with West Nile virus infection. Ocul Immunol Inflamm. 2007;15:435-9. https://doi.org/10.1080/ 09273940701798488.

164. Douam F, Ploss A. Yellow fever virus: Knowledge gaps impeding the fight against an old foe. Trends Microbiol. 2018;26:913-28.

165. Monath TP. Yellow fever: an update. Lancet Infect Dis. 2001;1:11-20.

166. World Health Organisation. Yellow fever. 2019. https://www. who.int/news-room/fact-sheets/detail/yellow-fever.

167. Vianello S, Silva de Souza G, Maia M, Belfort R, de Oliveira Dias JR. Ocular findings in Yellow fever infection. JAMA Ophthalmol. 2019;137:300-4.

168. Biancardi AL, Moraes HVde. Anterior and intermediate uveitis following Yellow fever vaccination with fractional dose: case reports. Ocul Immunol Inflamm. 2019;27:521-3.

169. Campos WR, Cenachi SPF, Soares MS, Gonçalves PF, Vasconcelos-Santos DV. Vogt-Koyanagi-Harada-like Disease following Yellow fever vaccination. Ocul Immunol Inflamm. 2019;1-4. https://doi.org/10.1080/09273948.2019.1661498.

170. Vannice K, Wilder-Smith A, Hombach J. Fractional-dose yellow fever vaccination-advancing the evidence base. N Engl J Med. 2018;379:603-5.

171. Mahendradas P, Avadhani K, Shetty R. Chikungunya and the eye: a review. J Ophthalmic Inflamm Infect. 2013;3:35.

172. Fritel X, Rollot O, Gerardin P, Gauzere BA, Bideault J, Lagarde $\mathrm{L}$, et al. Chikungunya virus infection during pregnancy, Reunion, France, 2006. Emerg Infect Dis. 2010;16:418-25. https://doi.org/ 10.3201/eid1603.091403.

173. Burt FJ, Chen W, Miner JJ, Lenschow DJ, Merits A, Schnettler E, et al. Chikungunya virus: an update on the biology and pathogenesis of this emerging pathogen. Lancet Infect Dis. 2017;17:e107-17. https://doi.org/10.1016/S1473-3099(16) 30385-1.

174. Mavalankar D, Shastri P, Bandyopadhyay T, Parmar J, Ramani KV. Increased mortality rate associated with Chikungunya epidemic, Ahmedabad, India. Emerg Infect Dis. 2008;14:412-5.

175. Lalitha P, Rathinam S, Banushree K, Maheshkumar S, Vijayakumar R, Sathe P. Ocular involvement associated with an epidemic outbreak of chikungunya virus infection. Am J Ophthalmol. 2007;144:552-6. https://doi.org/10.1016/j.ajo.2007. 06.002.

176. Babu K, Kini R, Philips M, Subbakrishna DK. Clinical profile of isolated viral anterior uveitis in a South Indian patient population. Ocul Immunol Inflamm. 2014;22:356-9.

177. Mahendradas P, Ranganna SK, Shetty R, Balu R, Narayana KM, Babu RB, et al. Ocular manifestations associated with chikungunya. Ophthalmology. 2008;115:287-91. https://doi.org/10. 1016/j.ophtha.2007.03.085.

178. Murthy KR, Venkataraman N, Satish V, Babu K. Bilateral retinitis following Chikungunya fever. Indian $\mathrm{J}$ Ophthalmol. 2008;56:329-31.

179. Scripsema NK, Sharifi E, Samson CM, Kedhar S, Rosen RB. Chikungunya-associated uveitis and exudative retinal detachment: a case report. Retin Cases Brief Rep. 2015;9:352-6.

180. Salceanu SO, Raman V. BMJ Case Rep. 2018. https://doi.org/10. 1136/bcr-2017-222864.

181. Mittal A, Mittal S, Bharati MJ, Ramakrishnan R, Saravanan S, Sathe PS. Optic neuritis associated with chikungunya virus infection in South India. Arch Ophthalmol. 2007;125:1381-6. https://doi.org/10.1001/archopht.125.10.1381.

182. Couderc T, Gangneux N, Chrétien F, Caro V, Le Luong T, Ducloux B, et al. Chikungunya virus infection of corneal grafts. J 
Infect Dis. 2012;206:851-9. https://doi.org/10.1093/infdis/ jis 296.

183. World Health Organisation. Chikungunya. 2020. https://www. who.int/news-room/fact-sheets/detail/chikungunya.

184. Mahendradas P, Shetty R, Malathi J, Madhavan HN. Chikungunya virus iridocyclitis in Fuchs' heterochromic iridocyclitis. Indian J Ophthalmol. 2010;58:545-7.

185. Ghildiyal R, Gabrani R. Antiviral therapeutics for chikungunya virus. Expert Opin Ther Pat. 2020;30:467-80. https://doi.org/10. 1080/13543776.2020.1751817.

186. Gao S, Song S, Zhang L. Recent progress in vaccine development against chikungunya virus. Front Microbiol. 2019;10:2881. https://doi.org/10.3389/fmicb.2019.02881.

187. Monsalve-Arteaga L, Alonso-Sardón M, Muñoz Bellido JL, Vicente Santiago MB, Vieira Lista MC, López Abán J, et al. Seroprevalence of Crimean-Congo hemorrhagic fever in humans in the World Health Organization European region: a systematic review. PLoS Negl Trop Dis. 2020;14:e0008094. https://doi.org/ 10.1371/journal.pntd.0008094.

188. Whitehouse CA. Crimean-Congo hemorrhagic fever. Antivir Res. 2004;64:145-60.

189. Bodur H, Akinci E, Ascioglu S, Öngürü P, Uyar Y. Subclinical infections with Crimean-Congo hemorrhagic fever virus, Turkey. Emerg Infect Dis. 2012;18:640-2.

190. CDC. Signs and symptoms I Crimean-Congo hemorrhagic fever (CCHF) | 2019;CDC. https://www.cdc.gov/vhf/crimean-congo/ symptoms/index.html.

191. Engin A, Erdogan H, Ozec AV, Elaldi N, Toker MI, Bakir M, et al. Ocular findings in patients with Crimean-Congo hemorrhagic fever. Am J Ophthalmol. 2009;147:634-8.e1. https://doi. org/10.1016/j.ajo.2008.11.014.

192. Ergönül Ö. Crimean-Congo haemorrhagic fever. Lancet Infect Dis. 2006;6:203-14.

193. World Health Organisation. Crimean-Congo haemorrhagic fever. 2013. https://www.who.int/news-room/fact-sheets/detail/crimea n-congo-haemorrhagic-fever.

194. Huang C, Wang Y, Li X, Ren L, Zhao J, Hu Y, et al. Clinical features of patients infected with 2019 novel coronavirus in Wuhan, China. Lancet. 2020;395:497-506. https://doi.org/10. 1016/S0140-6736(20)30183-5.

195. COVID-19 Dashboard by the Center for Systems Science and Engineering (CSSE) at Johns Hopkins University (JHU). https:// coronavirus.jhu.edu/map.html. Accessed 18 Jan 2021.

196. World Health Organisation. Transmission of SARS-CoV-2: implications for infection prevention precautions. Sci Brief. 2020. https://www.who.int/news-room/commentaries/detail/transmissionof-sars-cov-2-implications-for-infection-prevention-precautions.

197. Guan WJ, Ni ZY, Hu Y, Liang WH, Ou CQ, He JX, et al. Clinical characteristics of coronavirus disease 2019 in China. N Engl J Med. 2020;382:1708-20. https://doi.org/10.1056/NEJMoa 2002032

198. Xia J, Tong J, Liu M, Shen Y, Guo D. Evaluation of coronavirus in tears and conjunctival secretions of patients with SARS-CoV2 infection. J Med Virol. 2020;92:589-94.

199. Colavita F, Lapa D, Carletti F, Lalle E, Bordi L, Marsella P, et al. SARS-CoV-2 isolation from ocular secretions of a patient with COVID-19 in Italy with prolonged viral RNA detection. Ann Intern Med. 2020;173:242-3. https://doi.org/10.7326/M20-1176.

200. Marinho PM, Marcos AAA, Romano AC, Nascimento H, Belfort $\mathrm{R}$ Jr. Retinal findings in patients with COVID-19. Lancet. 2020;395:1610. https://doi.org/10.1016/S0140-6736(20) 31014-X.

201. Zhou Y, Zeng Y, Tong Y, Chen C. Ophthalmologic evidence against the interpersonal transmission of 2019 novel coronavirus through conjunctiva. medRxiv. 2020. https://doi.org/10.1101/ 2020.02.11.20021956.
202. Marinho PM, Marcos AAA, Romano AC, Nascimento H, Belfort R. Retinal findings in patients with COVID-19. Lancet. 2020;395:1610.

203. Thorlund K, Dron L, Park J, Hsu G, Forrest JI, Mills EJ. A realtime dashboard of clinical trials for COVID-19. Lancet Digit Health. 2020;2:e286-7. https://doi.org/10.1016/S2589-7500(20) 30086-8.

204. Dong J, Ismail N, Walker DH. Chapter 15-molecular testing in emerging infectious diseases. In: Diagnostic molecular pathology, editors. Coleman WB, Tsongalis GJ. Academic Press; 2017. p. 179-200. https://doi.org/10.1016/B978-0-12-800886-7. 00015-7.

205. Neumann G, Noda T, Kawaoka Y. Emergence and pandemic potential of swine-origin H1N1 influenza virus. Nature. 2009;459:931-9.

206. Paget J, Spreeuwenberg P, Charu V, Taylor RJ, Iuliano AD, Bresee J, et al. Global mortality associated with seasonal influenza epidemics: new burden estimates and predictors from the GLaMOR project. J Glob Health. 2019;9:020421. https://doi.org/ 10.7189/jogh.09.020421.

207. Otter JA, Donskey C, Yezli S, Douthwaite S, Goldenberg SD, Weber DJ. Transmission of SARS and MERS coronaviruses and influenza virus in healthcare settings: the possible role of dry surface contamination. J Hosp Infect. 2016;92:235-50. https:// doi.org/10.1016/j.jhin.2015.08.027.

208. Chan MC, Chan RW, Yu WC, Ho CC, Yuen KM, Fong JH, et al. Tropism and innate host responses of the 2009 pandemic H1N1 influenza virus in ex vivo and in vitro cultures of human conjunctiva and respiratory tract. Am J Pathol. 2010;176:1828-40. https://doi.org/10.2353/ajpath.2010.091087.

209. CDC. Flu symptoms \& complications. Centers for Disease Control and Prevention; 2019. https://www.cdc.gov/flu/ symptoms/symptoms.htm.

210. Yoser SL, Forster DJ, Rao NA. Systemic viral infections and their retinal and choroidal manifestations. Surv Ophthalmol. 1993:37:313-52.

211. Mansour DEAA, El-Shazly AA-F, Elawamry AI, Ismail AT. Comparison of ocular findings in patients with H1N1 influenza infection versus patients receiving influenza vaccine during a pandemic. Ophthalmic Res. 2012;48:134-8.

212. Roesel M, Heinz C, Heiligenhaus A. H1N1 and uveal effusion syndrome. Ophthalmology. 2010;117:1467-1467.e1.

213. Faridi OS, Ranchod TM, Ho LY, Ruby AJ. Pandemic 2009 influenza A H1N1 retinopathy. Can J Ophthalmol J Can Ophtalmol. 2010;45:286-7.

214. Rabon RJ, Louis GJ, Zegarra H, Gutman FA. Acute bilateral posterior angiopathy with influenza A viral infection. Am J Ophthalmol. 1987;103:289-93.

215. Jo T, Mizota A, Hatano N, Tanaka M. Frosted branch angiitislike fundus following presumed influenza virus type A infection. Jpn J Ophthalmol. 2006;50:563-4.

216. Rifkin L, Schaal S. H1N1-associated acute retinitis. Ocul Immunol Inflamm. 2012;20:230-2.

217. Lai CC, Chang YS, Li ML, Chang CM, Huang FC, Tseng SH. Acute anterior uveitis and optic neuritis as ocular complications of influenza A infection in an 11-year-old boy. J Pediatr Ophthalmol Strabismus. 2011;48:e30-3. https://doi.org/10.3928/ 01913913-20110628-03.

218. Cheung AY, Anderson B, Stec L, Khandhar P, Williams GA. Bilateral vaso-occlusive retinal vasculitis with $\mathrm{h} 1 \mathrm{n} 1$ influenza a infection. Retin Cases Brief Rep. 2015;9:138-41.

219. Nakagawa H, Noma H, Kotake O, Motohashi R, Yasuda K, Shimura M. Optic neuritis and acute anterior uveitis associated with influenza A infection: a case report. Int Med Case Rep J. 2017;10:1-5. https://doi.org/10.2147/IMCRJ. S113217. 
220. Pula JH, Issawi A, Desanto JR, Kattah JC. Cortical vision loss as a prominent feature of H1N1 encephalopathy. J Neuro-Ophthalmol J North Am Neuro-Ophthalmol Soc. 2012;32:48-50.

221. Breker DA, Stacey AW, Srinivasan A, Bursztyn LL, Trobe JD, Johnson MW. Vision loss caused by retinal and lateral geniculate nucleus infarction in $\mathrm{H} 1 \mathrm{~N} 1$ influenza. $J$ Neuroophthalmol. 2015;35:265-9. 0000000000000247

222. Tomás J, Macário MC, Gaspar E, Santana I. Severe postinfluenza (H1N1) encephalitis involving pulvinar nuclei in an adult patient. BMJ Case Rep. 2015;2015:bcr2015212667. https:// doi.org/10.1136/bcr-2015-212667.

223. CDC. Overview of influenza testing methods. 2019. https://www.cdc.gov/flu/professionals/diagnosis/overviewtesting-methods.htm.

224. Uyeki TM, Bernstein HH, Bradley JS, Englund JA, File TM, Fry AM, et al. Clinical practice guidelines by the Infectious Diseases Society of America: 2018 update on diagnosis, treatment, chemoprophylaxis, and institutional outbreak management of seasonal influenzaa. Clin Infect Dis. 2019;68:e1-47. https://doi.org/ 10.1093/cid/ciy866.

225. Simpson S, Kaufmann MC, Glozman V, Chakrabarti A. Disease $\mathrm{X}$ : accelerating the development of medical countermeasures for the next pandemic. Lancet Infect Dis. 2020;20:e108-15. https:// doi.org/10.1016/S1473-3099(20)30123-7.

226. Aiello F, et al. Coronavirus disease 2019 (SARS-CoV-2) and colonization of ocular tissues and secretions: a systematic review. Eye. 2020;1-6. https://doi.org/10.1038/s41433-0200926-9.
227. Walker DH, McCormick JB, Johnson KM, Webb PA, Komba-Kono G, Elliott LH, et al. Pathologic and virologic study of fatal Lassa fever in man. Am J Pathol. 1982;107:349-56.

228. Jones RM, Brosseau LM. Aerosol transmission of infectious disease. J Occup Environ Med. 2015;57:501-8.

229. Lam DSC, Wong RLM, Lai KHW, Ko CN, Leung HY, Lee VYW, et al. COVID-19: special precautions in ophthalmic practice and FAQs on personal protection and mask selection. Asia Pac J Ophthalmol. 2020;9:67-77. https://doi.org/10.1097/ APO.0000000000000280.

230. Olivia Li JP, Shantha J, Wong TY, Wong EY, Mehta J, Lin H, et al. Preparedness among ophthalmologists: during and beyond the COVID-19 pandemic. ophthalmology. 2020;127:569-72. https://doi.org/10.1016/j.ophtha.2020.03.037.

231. Khairallah M, Jelliti B, Jenzeri S. Emergent infectious uveitis. Middle East Afr J Ophthalmol. 2009;16:225-38. https://doi.org/ 10.4103/0974.9233.58426.

232. Hasbun R, Garcia MN, Kellaway J, Baker L, Salazar L, Woods SP, et al. West Nile Virus retinopathy and associations with long term neurological and neurocognitive sequelae. PLoS ONE. 2016;11:e0148898. https://doi.org/10.1371/journal.pone. 0148898.

233. Mahendradas $\mathrm{P}$, Avadhani K, Shetty R. Chikungunya and the eye: a review. J Ophthalmic Inflamm Infect. 2013;3:35. https:// doi.org/10.1186/1869-5760-3-35.

234. Lopez-Prats MJ, Sanz Marco E, Hidalgo-Mora JJ, GarciaDelpech S, Diaz-Llopis M. Bleeding follicular conjunctivitis due to influenza H1N1 virus. J Ophthalmol. 2010;2010:423672. https://doi.org/10.1155/2010/423672. 